\title{
Management of water resources in semi-arid: assessment of the drinking water supply in rural communities of Chapada do Apodi-RN
}

Gestão dos recursos hídricos no semiárido: avaliação do abastecimento de água para consumo humano nas comunidades rurais da Chapada do Apodi-RN

Jorge Luís de Oliveira Pinto Filho

Alana Ticiane Alves do Rêgo ${ }^{b}$ Anderson Rodrigues da Silva Lunes ${ }^{c}$

aUniversidade Federal Rural do Semi-Árido - Ufersa, Campus Pau dos Ferros, Pau dos Ferros, RN, Brasil.

E-mail: jorge.filho@ufersa.edu.br ${ }^{b}$ Universidade Federal Rural do Semi-Árido - Ufersa, Campus Pau dos Ferros, Pau dos Ferros, RN, Brasil.

E-mail: alana_ticiane10@hotmail.com 'Universidade Federal Rural do Semi-Árido - Ufersa, Campus Pau dos Ferros, Pau dos Ferros, RN, Brasil. E-mail: anderson_lunes@hotmail.com doi:10.18472/SustDeb.v10n3.2019.24398 


\begin{abstract}
Water is a natural resource, present in metabolic processes of living beings, which has been used for various purposes, especially human consumption. This study aimed to evaluate the system of supply and the quality of water for human consumption in rural communities of Chapada do Apodi, RN. The methodology consisted of identifying and evaluating the supply system as well as the quality of the water from the environmental perception and physical-chemical and biological analyses in water. Electrical conductivity, turbidity, dissolved oxygen, and Total Residue showed standards required for human consumption according to values presented by current legislation. On the other hand, the results for $\mathrm{pH}$ parameters, total coliforms, and coliforms Escherichia coli type termotolerantes showed disagreement in accordance with the laws concerning the limits established for water bodies of water intended for human consumption. The infrastructural conditions of water supply systems, as well as the physical and chemical parameters of untreated water, were considered unsatisfactory.
\end{abstract}

Keywords: Traditional rural communities. Water supply. Domestic consumption of water. Waterborne diseases.

\title{
RESUMO
}

A água é recurso natural, presente em processos metabólicos dos seres vivos, que vem sendo utilizada para diversos fins, em especial o consumo humano. $O$ estudo objetivou avaliar o sistema de abastecimento e a qualidade da água para consumo humano das comunidades rurais da Chapada do Apodi, Rio Grande do Norte. A metodologia constou de identificação e avaliação do sistema de abastecimento a partir da percepção ambiental e de análises físico-químicas e biológicas na água. Os dados de condutividade elétrica, turbidez, resíduo total e oxigênio dissolvido apresentaram padrões aceitáveis para o consumo humano de acordo com valores apresentados pela legislação vigente. Em contrapartida, os resultados encontrados para os parâmetros de $\mathrm{pH}$, coliformes totais e coliformes Termotolerantes do tipo Escherichia coli apresentaram discordância com a legislação para corpos hídricos de águas doces destinados ao consumo humano. Podem-se considerar como insatisfatórias as condições de infraestrutura dos sistemas de abastecimento de água e os parâmetros físico-químicos da água sem prévio tratamento.

Palavras-chave: Comunidades rurais tradicionais. Abastecimento de Água. Consumo Doméstico de Água. Doenças de Veiculação Hídrica.

\section{INTRODUCTION}

Water is an important natural resource and it is present in most metabolic processes of living beings, constituting an element of vital importance for their survival. Depending on its quality, it can be used for various purposes, such as human consumption, agricultural and livestock activities, electricity generation, waterway transportation, industrial use, fishing and aquaculture, tourism and leisure (DERÍSIO, 2012). These multiple uses can result in changes in the physicochemical and biological characteristics of water through processes of pollution and/or contamination, causing social, economic, political, environmental, ecological and health-related consequences.

This natural resource is used worldwide, but it becomes particularly relevant in semi-arid regions, due to its climate specificities. In the case of the brazilian Northeast, strategies concerning water resources management is notorious, since such resources are ultimate for territorial planning. From the perspective of multiple uses of water resources, Chapada do Apodi has been adopting an economic model based on the implementation of irrigated perimeters, which facilitate access to water resources.

Chapada do Apodi spreads across the states of Ceará and Rio Grande do Norte, surrounding the cities of Apodi, Baraúna, Felipe Guerra, and Governor Dix-Sept Rosado, in the state of Rio Grande 
do Norte, and Alto Santo, Jaguaruana, Limoeiro do Norte, Quixeré and Tabuleiro do Norte, in the state of Ceará (PINTO et al., 2016).

The agricultural production model based on irrigated perimeters in Chapada do Apodi is a prevalent practice in agribusiness, which according to Rigotto and Teixeira (2009), has consequences related to work, environment and health: land concentration and population displacement; violence; food safety risks; social changes; imposition of new habits; formation of rural slums; intensive use of mechanization; use of fertilizers and pesticides; precarious working relations and conditions; non-compliance with labor legislation; intensification of work; health-risk exposure; reduction of biodiversity and environmental services; soil degradation; high water consumption; air contamination; water pollution; exposure of workers and surrounding communities to pesticides.

Because of the aforementioned scenario of agricultural production, Chapada do Apodi has been the object of scientific studies with several approaches: workers' conditions (SAMPAIO; LIMA; FREITAS, 2011); public health, land concentration, environmental, social and political-related issues (RIGOTTO, 2011), and pesticides (CARNEIRO; RIGOTTO; PIGNATI, 2012). However, these studies are particularly focused on the limits of Chapada do Apodi in the state of Ceará, therefore further investigation in Rio Grande do Norte is needed.

The relevance of the present study accounts for the lack of scientific studies in Chapada do Apodi/ RN. It is, therefore, urgent to address environmental problems in the region, which are related to the early stages of the implementation of Santa Cruz do Apodi Irrigated Perimeter and the establishment of agricultural companies. Such issues impact on environmental quality, especially water resources, as they are an indispensable natural element for this economic sector and also necessary for regional human development.

In Brazil, several studies on water supply have been developed, especially: Amaral et al. (2003), Araújo et al. (2011), Bortoli et al. (2018), Brum et al. (2016), Cavalcante (2014), Giatti (2007), Lemos (2003), Medeiros, Lima e Guimarães (2016), Morais et al. (2017), Pessôa (2013), Pinto Filho et al. (2018), Quesado Júnior et al. (2008), Soares et al. (2018) e Souza et al. (2016). However, similar studies have not yet been conducted in Chapada do Apodi/RN, being important for providing data on local environmental sanitation, which will allow to inhibit, or prevent the occurrence of diseases.

Taking that into account, it is relevant to investigate the water supply system for human consumption in the communities of Chapada do Apodi/RN, since it is a scenario in the Brazilian semi-arid region with deficiencies in environmental sanitation conditions, climate specificities and agroindustrial influence. An investigation of this context can be carried out through environmental perception, which is a kind of approach that considers the representations a population has about their environment (DEL RIO; OLIVEIRA, 1996) and, through the monitoring of water, looking at changes in its quality characteristics which might result from anthropic activities and natural phenomena (TUCCl, 2006). Following such investigative approach, it is possible to identify the relations between environmental conditions and population.

This study aims to identify the environmental perception of the local population, for it is considered as an instrument that sheds light on the understanding about the interrelationships between society and the environment (MELAZO, 2005). In addition to that, water monitoring will be administered, with the objective to verify whether legal standards of water quality are being obeyed, as well as to identify what is being changed, and to understand the reasons that justify such changes (TUCCl, 2006).

In this perspective, in addition to the environmental perception data, water monitoring is likewise necessary to reduce the pressure of anthropogenic degradation on aquatic ecosystems, as it allows to know the conditions of adaptability of the environment and the loads of polluting agents, 
enabling the aid of planning when it comes to decision making (MAROTTA; SANTOS; ENRICH-PRAST, 2008). However, the unavailability of water quality data is one of the central problems of developing countries (BHATTI; LATIF, 2011), which increases the relevance of this research.

Taking this discussion into account, this study presents a systematic approach to the problem investigated: it is environmentally-based, for taking into account the quality of water for human consumption; it is socially-based for identifying the role of water in local development; it is also economically-based for analyzing the effects of water scarcity in the region; scientifically-based for contributing to water quality studies in semi-arid areas; technically-based for providing data to official environmental agencies; and ultimately, this study is politically-based for investigating how water has been used and for whom it should be prioritized.

Bearing that in mind, the objective of this work is to evaluate the water supply system for human consumption in the rural communities of Chapada do Apodi/RN. For this, the following specific objectives were listed: a) to identify the forms of water supply for the population in the study area; b) to evaluate the supply system from the environmental perception of the population and c) to analyze the physicochemical and biological quality in water for human consumption.

\section{MATERIAL AND METHODS}

\subsection{RESEARCH CLASSIFICATION}

The present study can be classified according to its approach, type, objectives, sources, and techniques (GIL, 2008). This research follows a qualitative approach, as it presents an evaluation of the human supply system in communities surrounding Chapada do Apodi/RN based on environmental perception. Furthermore, such investigation is also quantitative, once it analyzes aspects regarding water quality. This kind of research has its roots in a logical positivist thinking, which tends to emphasize deductive reasoning, logic rules, and the measurable attributes of human experience (FONSECA, 2002).

This kind of research can be categorized as a case study, because it evaluates the specificity of water supply and its relationship with Santa Cruz do Apodi Irrigated Perimeter. Gil (2008) points out that a case study is a detailed analysis of one or a few objects so that its in-depth knowledge can be obtained through the investigation of a phenomenon within its real context.

This study has an explanatory objective, since it seeks to identify the supply system from the local population's environmental perception. According to Gil (2008), exploratory research aims to identify the factors that determine or contribute to the occurrence of phenomena.

In order to implement this research, different means of data collection strategies were adopted, such as bibliographic research, document analysis and field observation (documentation research, interviewing, observation and chemical analysis) (GIL, 2008).

\subsection{STUDY AREA DELIMITATION AND CHARACTERIZATION}

Apodi is a municipality located in the microregion of Chapada do Apodi and in the western potiguar mesoregion of Rio Grande do Norte (Figure 1). It is $340 \mathrm{~km}$ away from Natal, and its territorial area reaches $1,602,477 \mathrm{~km}^{2}$ (IBGE, 2018). 


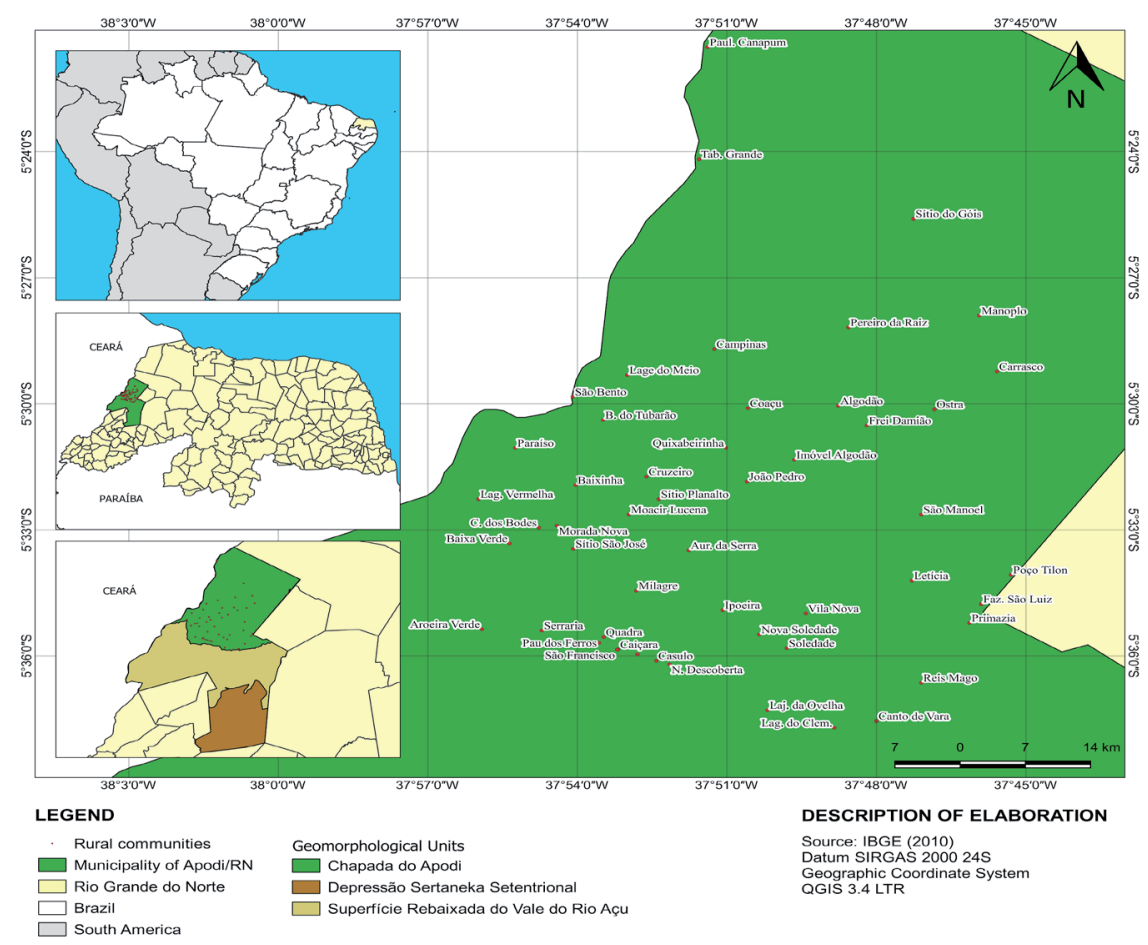

Figure 1: Location map of Apodi municipality, Rio Grande do Norte (RN), and rural communities of Chapada do Apodi / RN.

Source: Authors (2019).

The municipality of Apodi/RN has a population of 35,814 inhabitants, most of whom are located in rural areas (almost 52\%) (IBGE, 2018). The rural area of Apodi is characterized according to its geological formations and it is divided in the following rural zones: Açu Formation (Apodi Sand Region); Crystal Basement and Northern Country Depression (Apodi Stone Region); Alluvial Deposits (Apodi Valley); and Jandaíra (Chapada do Apodi) (Figure 1).

The region of Chapada do Apodi/RN had its territorial planning process over the years with agricultural activities. Some decades ago it was occupied by large farms, however, in the late 1970s and early 1980s, with the emergence of rural community associations created by actions carried out by churches through the Basic Ecclesial Communities - CEBs, a process of popular organization of rural workers came to exist in Apodi. (PONTES, 2012).

The articulate work of Apodi farmers culminated in the 1990s, with the creation of the Apodi Workers and Rural Workers Syndicate (Sindicato dos trabalhadores Rurais de Apodi-STTR), an important articulator of family farming in the region. From 1990, Apodi began to manifest changes in the rural context caused by the cotton crisis, which was characterized by biological pests, the increasing use of pesticides, scarcity of economic resources, high interest rates for financing production, lack of scale economy, and restriction in agricultural mechanization. This scenario resulted in the weakening of great landowners, which somehow encouraged local workers to fight for agricultural reformation (PONTES, 2012).

Consequently, small-holder farmers obtained their land through expropriations carried out by the National Institute of Agrarian Reform - Incra, and rural communities from the Land Credit, an important public policy instrument for access to land throughout the Country. In Chapada do Apodi/RN, where large states were once predominant, is nowadays characterized by several settlements and traditional rural communities which work with agroecological family farming (PONTES, 2012).

As a result, in this area, successful experiences of agroecological and family farming in the Northeast have been consolidated in recent years, covering 55 rural communities (Figure 1 and Table 1) (PONTES et al., 2013). Table 1 shows the geographical coordinates of the rural communities of Chapada do Apodi / RN of this study. 
Table 1 | Geographic coordinates of rural communities of Chapada do Apodi-RN.

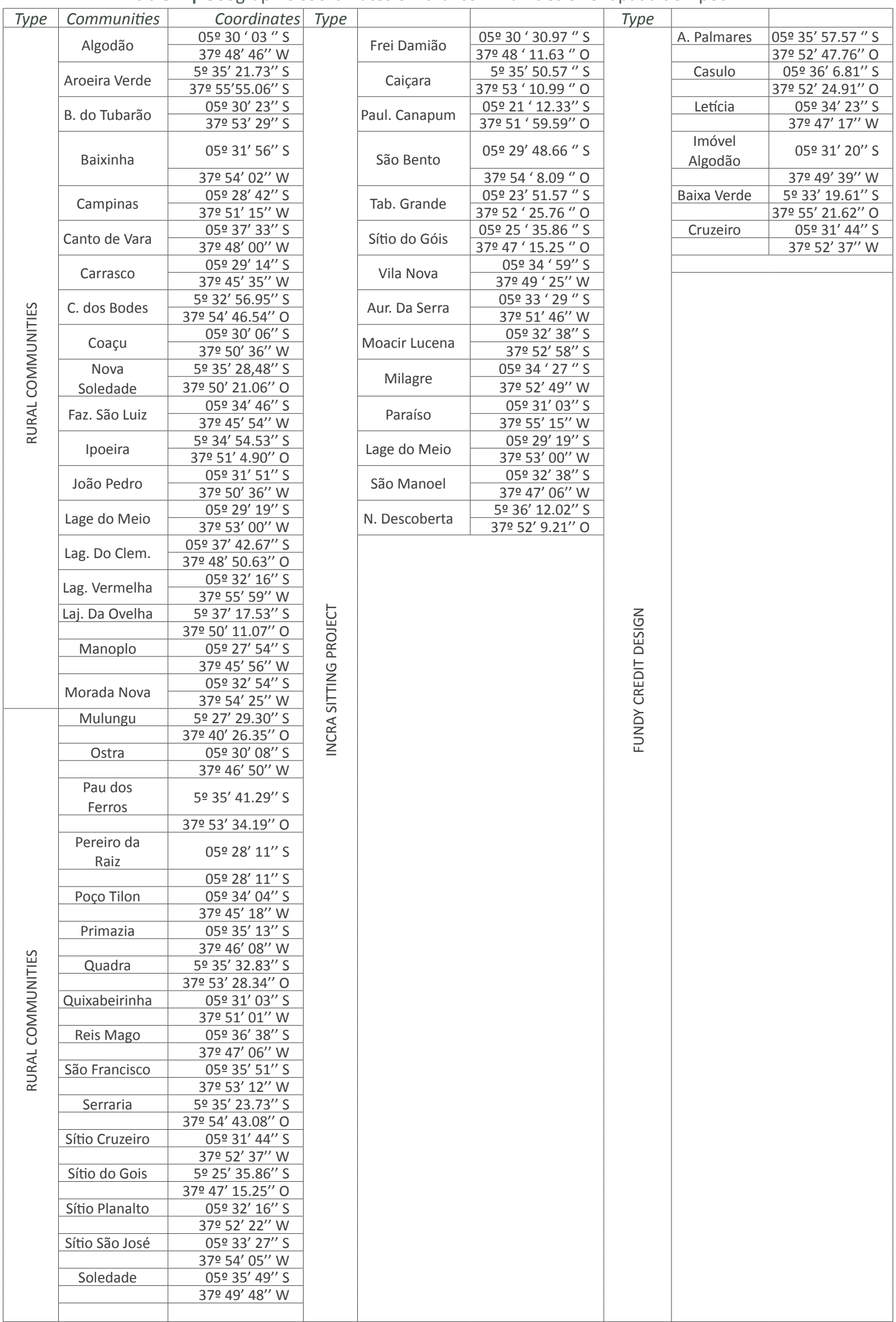




\subsection{THEORETICAL AND METHODOLOGICAL PROCEDURES OF ENVIRONMENTAL PERCEPTION}

To investigate the problem of the study area, an environmental perception approach was used. This research strategy is considered a sustainability tool through which society and nature are put into communion, therefore allowing us to understand the conditions of the water supply system for human consumption in rural communities, as well as to identify the reflection of these conditions on the community's quality of life. Regarding this methodology, the following procedures were set: a) definition of the instrument for collecting environmental perception; b) sampling process; c) field research and; d) data processing. It is also relevant to emphasize that the perception of the local community is considered an indicator of management effectiveness. Rodrigues et al. (2012) state that this instrument allows the monitoring of services in the lives of residents.

\section{A) ENVIRONMENTAL PERCEPTION COLLECTION INSTRUMENT}

A semi-structured questionnaire addressing the socioeconomic profile of the local population was adopted as a tool for collecting environmental perception; characteristics of water uses for human consumption; evaluation of supply water quality and quantity; and the most common diseases in the investigated region to possibly correlate with water disease vectors.

\section{B) SAMPLING PROCESS}

The study sampling process was carried out by drawing at least $10 \%$ of the households. We used as data source the Basic Health Unit (Unidade Básica de Saúde) - UBS (2018) of rural communities belonging to the investigated region which accounted for 1,649 households.

Based on that, water samples were collected from 186 households. This value has been set by Bolfarine and Bussab (2005) who consider that a sample equal to or greater than 25 will always be considered normal, i.e. significant. Therefore, a non-probabilistic sample was established, in which this number represents more than $10 \%$ of the total local population (Table 1).

The defined sample consisted of 186 questionnaires which represent $11.28 \%$ of the total of households, being distributed proportionally among the rural communities investigated and matching the statistical requirements (Table 2 ).

Table 2 | Population Distribution of rural communities of Chapada do Apodi-RN.

\begin{tabular}{|c|c|c|c|c|c|c|c|c|}
\hline TYPE & COMMUNITIES & $\begin{array}{c}\text { HOUSEHOLDS } \\
\text { SAMPLE }\end{array}$ & TYPE & COMMUNITIES & $\begin{array}{c}\text { HOUSEHOLDS } \\
\text { SAMPLE }\end{array}$ & TYPE & COMMUNITIES & $\begin{array}{c}\text { HOUSEHOLD } \\
\text { SAMPLE }\end{array}$ \\
\hline \multirow{14}{*}{ 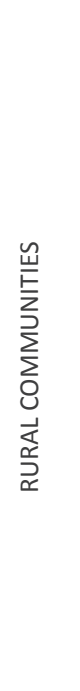 } & Algodão & $07-01$ & \multirow{14}{*}{ 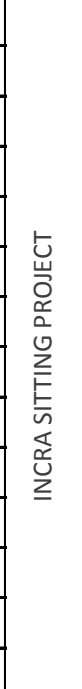 } & Frei Damião & $50-05$ & \multirow{14}{*}{ 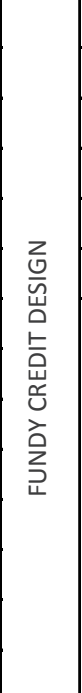 } & Agrovila Palmares & $30-03$ \\
\hline & Aroeira Verde & $03-01$ & & Caiçara & $60-06$ & & Casulo & $12-02$ \\
\hline & B. do Tubarão & $10-01$ & & Paul. Canapum & $60-06$ & & Letícia & $15-02$ \\
\hline & Baixinha & $03-01$ & & São Bento & $45-04$ & & Imóvel Algodão & $17-02$ \\
\hline & Campinas & $15-02$ & & Tab. Grande & $60-06$ & & Baixa Verde & $51-06$ \\
\hline & Canto de Vara & $10-01$ & & Sítio do Góis & $60-06$ & & Cruzeiro & $07-01$ \\
\hline & Carrasco & $04-01$ & & Vila Nova & $10-01$ & & & \\
\hline & C. dos Bodes & $01-01$ & & Aur. da Serra & $70-07$ & & & \\
\hline & Coaçu & $01-01$ & & Moacir Lucena & $25-03$ & & & \\
\hline & Nova Soledade & $01-01$ & & Milagre & $32-04$ & & & \\
\hline & Faz. São Luiz & $10-01$ & & Paraíso & $36-04$ & & & \\
\hline & Ipoeira & $07-01$ & & Lage do Meio & $28-03$ & & & \\
\hline & João Pedro & $18-02$ & & São Manoel & $26-03$ & & & \\
\hline & Lage do Meio & $100-10$ & & N. Descoberta & $42-05$ & & & \\
\hline
\end{tabular}




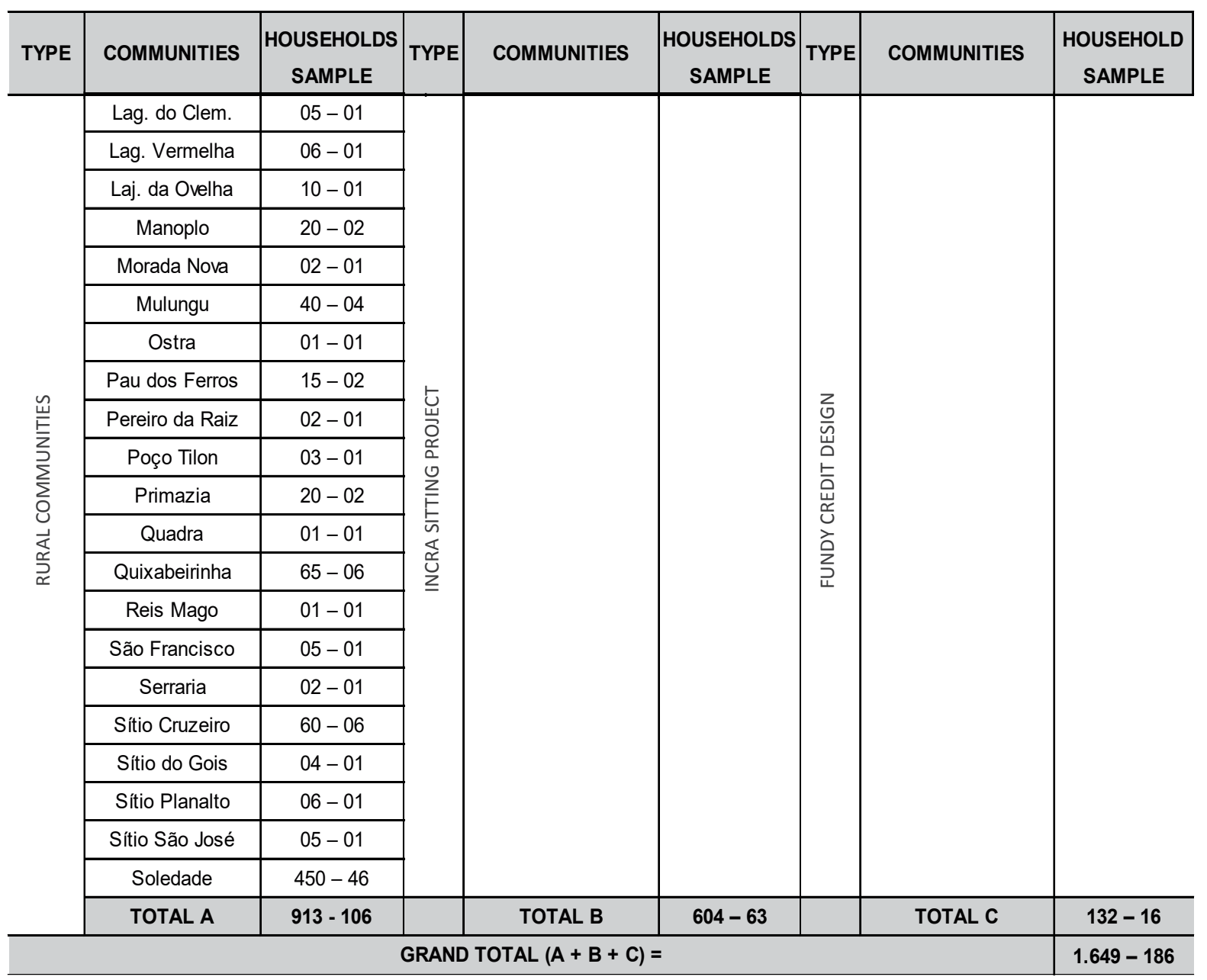

Source: Authors (2019).

\section{C) FIELD RESEARCH}

In January, February and March, 2018, the questionnaires were applied to the rural communities investigated. The Informed Consent Form (ICF) was made available to the participants, including the research explanations and general information about the researchers. The inclusion and exclusion criteria of participants and the research risks were likewise mentioned. The choice of the survey method was due to its descriptive, explanatory and exploratory statements about a population, i.e. to discover the distribution of attributes of the investigated population (BABBIE, 2001).

The monitoring of water quality for human consumption took place through analysis of physicochemical parameters in the reservoirs of households (cisterns, wells, water tanks, and taps). This monitoring was based on the American Public Health Association - APHA (1995), using multiparameter probe, model HORIBA U-50, which allows real-time quantification of hydrogen potential ( $\mathrm{pH})$, turbidity (NTU),

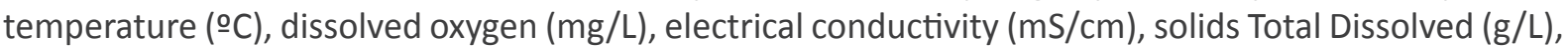
Salinity (ppt), Oxidation Reduction Potential $(\mathrm{mV})$ and Percent Dissolved Oxygen (\%). Total coliforms (UFC/100mL), thermotolerant coliforms (UFC/100mL) and Escherichia coli (UFC/100mL) were performed in a commercial laboratory.

\section{D) DATA PROCESSING}

The results were submitted to nonparametric statistical analysis by Spearman correlation, the same procedure used by Ribeiro et al. (2016) and Bertossi et al. (2013). Data was processed through Microsoft Office Excel, version 2013, and through graphing of boxplot type of each variable. The correlation matrix 
composed of the 10 variables was processed using a free statistical software, R studio, which shows the relationship between the selected variables in each component. The results were compared with studies of water supply in rural communities, according to Resolution values of National Environment Council - Conama N 357/2005 and the Ordinance of the Ministry of Health N²,914 / 2011.

\section{RESULTS AND DISCUSSION}

\subsection{WATER SUPPLY SYSTEM IN RURAL COMMUNITIES OF CHAPADA DO APODI/RN VIA ENVIRONMENTAL PERCEPTION OF LOCAL POPULATION}

The distribution of water supply system from communities of Chapada do Apodi occurs in an heterogeneous way, in time and space, with quantitative limitation, and presenting source variation: wells $(85,07 \%)$, Sanitation Company of the State of Rio Grande do Norte (Companhia de Águas e Esgotos do Rio Grande do Norte - Caern) (3,73\%) Tank truck (3,36\%), wells and Tank trucks (4,10\%), wells and Cern $(0,37 \%)$, and others (3,36\%). Similar results about supply infrastructure have been found by Amaral et al. (2003), Giatti (2007) and Pinto Filho et al. (2018) when the difficulties of rural communities in accessing potable water were analyzed by their research. Thus, it can be induced that there is an unequal and difficult relation concerning the access to potable water by rural population of Chapada do Apodi/RN.

Through the local population perception, the existence of deficiencies in the water supply was noticed, especially regarding the absence of water distribution system. To solve this kind of problem, Souza et al. (2016) point to the adoption of alternative collective solutions in supplying the consumption necessities. Inserting the possibilities of a viable alternative, Morais et al. (2017) emphasize social technologies of water collection and storage in addition to actions of environmental education (which is a sensibilization and transformation vehicle) for stimulation of the strengthening and use of sanitation barriers that preserve the quality of this natural resource.

Still in this conception, Amaral et al. (2003) assert that water, when taken from natural sources without any treatment, results in a deficiency in the water supply system, consequently presenting possible coliform contamination and risk of water-borne infections. It can be seen from the present research that $72 \%$ of the population consumes water without any previous treatment, $18.66 \%$ use ceramic filters in their homes, $5.60 \%$ use chlorine for disinfection to inactivate organisms. Referring to pathogens, only $0.75 \%$ carry out a boil pretreatment as a preventive measure, and $2.99 \%$ answered that they treat water by using other procedures. Similar situations were found by other researchers, such like Lemos (2003), who made his study in rural area of Maquiné/RS, where $87 \%$ of population does not previously treat the collected water, and like Bortoli et al. (2018) who observed that from water samples intended for human consumption in rural properties located in Rio Grande do Sul, only 58\% received chlorine treatment, and the remaining percentage do not use any treatment. Therefore, it is clear that the water supply for human consumption in rural areas still is a recurring problem, consequently making the local population vulnerable to water-borne diseases.

It is well known that Inadequate sanitation conditions in rural areas, correlated with the lack of information of the population, enable the development of water-borne diseases (ARAÚJO et al., 2011; CAVALCANTE, 2014). In the investigated rural communities, problems in the water supply system were enough to influence human health, since the occurrence of some symptoms and diseases, such as diarrhea (11.9\%), typhoid fever (7.0\%), and dengue (1.9\%), which are amongst the most mentioned by the population of the study (Figure 2). In the study carried out by Pinto Filho et al. (2018), residents from rural communities of CPCA/RN mentioned health problems associated with water quality, including diarrhea (10.5\%), and dengue (3.4\%). Taking these figures into account, it can be assumed the evident connection between water quality and the emergence of water-borne diseases (BRUM et al., 2016; SOARES et al., 2018). 


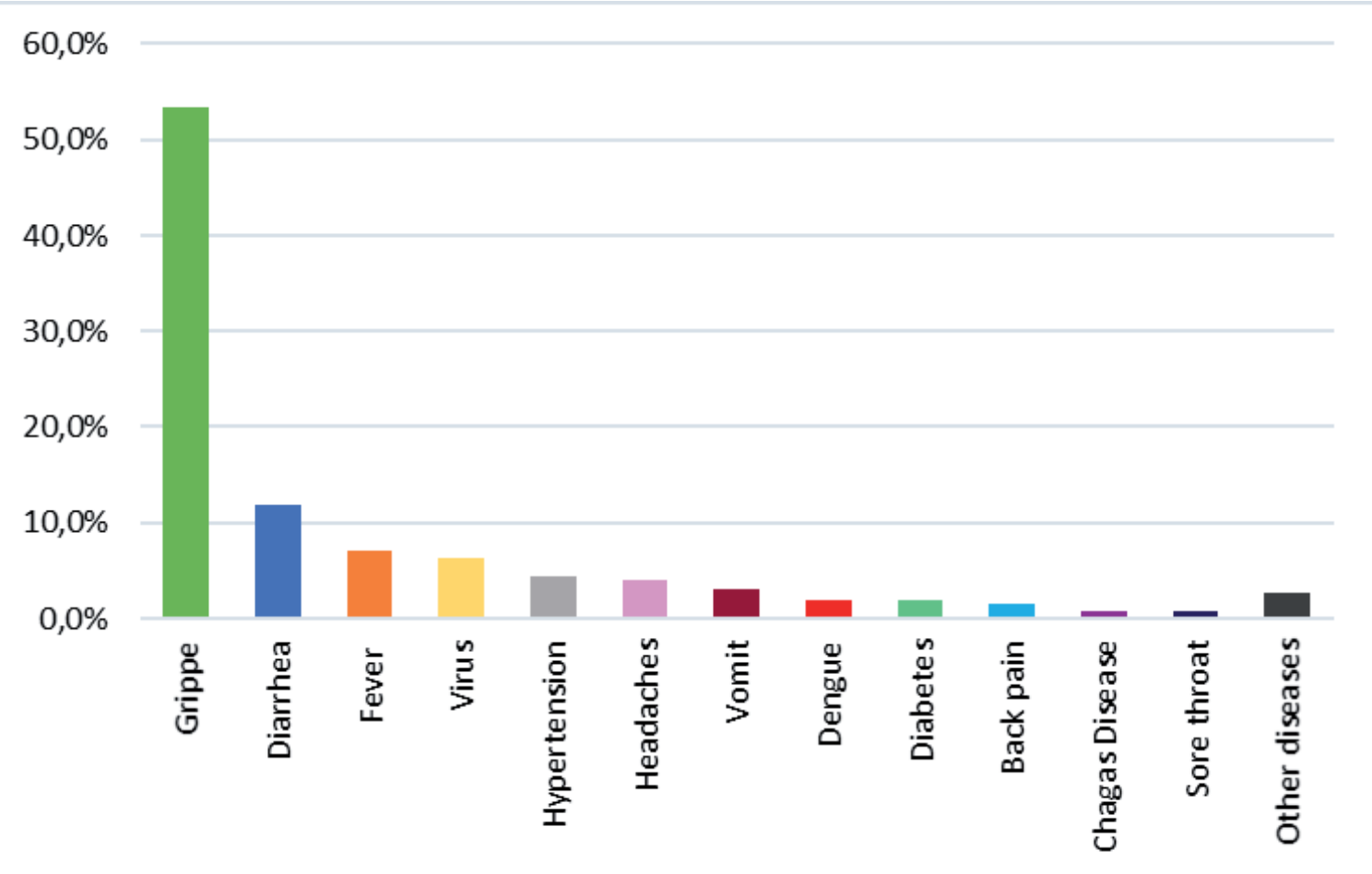

Figure 2: Symptoms and diseases cited by inhabitants of Chapada do Apodi communities. Source: Authors (2019).

Thus, to associate health and environmental quality, it is necessary to analyze the water condition for human consumption in the rural communities studied. Since the lack of monitoring of these sources and the lack of information of the population about the causes and problems associated with contamination contribute to a greater incidence of waterborne diseases. (CAVALCANTE, 2014).

\subsection{WATER QUALITY OF THE HUMAN CONSUMPTION SUPPLY SYSTEM IN THE RURAL COMMUNITIES STUDIED}

Table 3 contains the physicochemical (temperature, $\mathrm{pH}$, redox potential, electrical conductivity, turbidity, dissolved oxygen, total residue, and salinity) and biological (thermotolerant coliforms E.coli) variables for drinking water samples in rural communities of Chapada do Apodi / RN.

In bodies of water, temperature can be analyzed along with other parameters, and may also influence the reactions of this vehicle (NOGUEIRA, COSTA e PEREIRA, 2015). The values obtained in the analysis for temperature presented an average of $29.14{ }^{\circ} \mathrm{C}$ (Table 3). However, the rural community of $\mathrm{A}$. Palmares showed an excessive temperature of $33,05^{\circ} \mathrm{C}$ (row 174 and column 02, Table 3). A similar result was observed in a study by Araújo et al. (2011), which demonstrated excessive values, up to 30.1 ${ }^{\circ} \mathrm{C}$, in a community from the state of São Paulo. Current brazilian legislation does not establish values for a temperature parameter, so it is not possible to reference as legal non-compliance.

The hydrogenic potential - $\mathrm{pH}$ may be the result of natural and anthropogenic factors (LIBANIO, 2005). The $\mathrm{pH}$ values of the studied water samples presented an average of 5.92 (Table 3), and in the rural community of Paraíso, analysis 01, it could be observed value of 4.120 (row 132 and Column 03, Table 3). Thus, the minimum and average values are not under the Conama Resolution No. 357/2005 and Ordinance MS No. 2.914 / 2011, which provide for the maximum values between 6.0 to 9.0 and 6.0 to 9.5 , respectively. 
These results showed similar quality to values obtained by Medeiros, Lima, and Guimarães (2016) from groundwater source waters in municipalities of Pará state, the samples revealed acid values that do not match the recommended values for human consumption; by Brum et al. (2016), which ranged values between 4.46 to 6.96, in shallow wells from an area with lack of basic sanitation in Cuiabá/MT; and by Araújo et al. (2011) who obtained data of 4.25 and 4.46, from a residential water tank and from one of the springs that supply the rural communities in the state of São Paulo. Therefore, it is observed a tendency for waters in rural areas to have acidic quality.

Redox potential - ORP represents changes in the oxidation state of several ions or nutrients and it is related to nutrient availability for aquatic communities (TUNDISI; TUNDISI, 2008). The values of ORP found presented an average of 292,566 mV (Table 3) and values that indicated up to $383.0 \mathrm{mV}$ in relation to the rural communities of: São Bento, analysis 02 (row 127 and Column 04); Aur. da Serra, analysis 03 (Line 145 and Column 04); Lage do Meio, analysis 02 (Line 162 and Column 04); A. Palmares, analysis 01 (Line 172 and Column 04); and Real Estate Cotton, analysis 02 (Line 180) and Column 04). The Conama Resolution does not have redox potential standards for freshwater classes. However, according to Fiorucci and Benedetti Filho (2005), ORP values between $200 \mathrm{mV}$ and $600 \mathrm{mV}$ indicate a strongly oxidizing vehicle, and differences of potential between $-100 \mathrm{mV}$ and $-200 \mathrm{mV}$ reveal reducing ones. Thus, it is possible to evaluate the quality of water samples from Chapada do Apodi/RN as considerably oxidizing.

The electrical conductivity - EC represents a measure of the anthropic effect, since it depends on the ionic concentrations and temperature, indicating the existence of salts in the water (SÃO PAULO STATE ENVIRONMENTAL COMPANY - CETESB, 2010). EC results indicated an average of $138.565 \mu \mathrm{S} /$ $\mathrm{cm}$ (Table 3), and presented values up to $843 \mu \mathrm{S} / \mathrm{cm}$, as in the rural community of B. do Tubarão, analysis 01 (row 04 and column 05, Table 3), values considered above than allowed, given that the Ordinance MS No. 2,914/2011 establishes a standard of acceptance for consumption a limit of $1,000 \mu \mathrm{S} / \mathrm{cm}$ (BRAZIL, 2011). When compared to the results of Brum et al. (2016) significant differences were observed, since these authors found values up to $486.7 \mu \mathrm{S} / \mathrm{cm}$, representing that the investigated samples are inside the limit established by the ordinance. However, controlling these concentrations under the limits of the legislation is an important tool to avoid the degrading effects of the water pollution process (TUNDISI, 2003).

Turbidity - Turb can be of both natural and anthropogenic origin and does not pose direct problems, but it is aesthetically unpleasant; moreover suspended solids can provide refuge for pathogenic microorganisms (PERPÉTUO, 2014). The results obtained from Turb reached an average of 12,998 Nephelometric Turbidity Units (UNT) (Table 3). However, in the rural community of N. Descoberta, analysis 05 (Row 171 and Column 06 , Table 3 ), this parameter showed a surplus value of 420 UNT.

The average data analyzed was lower than the maximum allowable limit (up to 40 UNT) proposed by Conama Resolution No. 357/2005 for Class 1 freshwater supplies for human consumption with disinfection, indicating that they are in accordance with the conditions established by law. When compared to the Ordinance MS No. 2,914 / 2011, it is observed that the average presented results considered not acceptable for human consumption, for its value was above the recommended limit of 5 UNT, which requires previous treatment for consumption. We also emphasize that the results obtained for Turb were also different and superior to those determined by other studies of water evaluation, such as Pinto Filho et al. (2018), which determined values up to 6.61 UNT. It can be inferred that some values found were above the standard established by current legislation, therefore, the organoleptic characteristics of water may be compromised.

Dissolved oxygen - OD is the main parameter for characterizing the effects of water pollution by organic waste (VON SPERLING, 2005). This element influences all chemical and biological processes that occur in water and indicates possible pollution by organic matter (ESTEVES, 2011). In the analyzed samples, the OD values expressed an average of $9.75 \mathrm{mg} / \mathrm{L}$ (Table 3 ) and, in the rural community of São Francisco, analysis 03 (Row 47 and Column 07, Table 3) showed a value corresponding to 4,92 mg/L, favoring a negative value 
according to Conama Resolution No. 357/2005. The MS Ordinance No. 2.914/2011 does not establish values for this parameter.

When comparing with data from the literature, it is observed that the results obtained were superior, since Pinto Filho et al. (2018) obtained values ranging from 3.89 to $7.60 \mathrm{mg} / \mathrm{L}$ in water collected for human consumption in the CPCA / RN, and presented a total of $84.51 \%$ of the samples below $6.0 \mathrm{mg} / \mathrm{L}$ and; Araújo et al. (2011), found values between 2.7 and $8.3 \mathrm{mg} / \mathrm{L}$ in water samples collected in rural communities in the state of São Paulo. So, the obtained values with low dissolved oxygen levels may be related to the waste of organic substances in water bodies and its decomposition by aerobic microorganisms that consume dissolved oxygen present in water (ARAÚJO et al., 2011; PESSÔA, 2013).

Total residue - STD is considered a potential problem: its excess in water causes changes in taste, leads to corrosion problems of pipes and its consumption can cause risks to human health (CASALI, 2008) The values found in this study presented an average of $279 \mathrm{mg} / \mathrm{L}$ (Table 03), but in the rural communities of Poço Tilon, analysis 02 (Row 39 and Column 09, Table 3); Quixabeirinha, analysis 02 (Row 43 and Column 09, Table 3); São Francisco, Analysis 04 (Row 48 and Column 09, Table 3); Aur. da Serra, analysis 04 (Row 146 and Column 09, from Table 3); Lage do Meio, analysis 03 (Row 163 and Column 09, from Table 3); and Baixa Verde, analysis 04 (Row 184 and Column 09, from Table 3), values of 1,584 mg/L were obtained. When compared with Conama Resolution 357/2005, to classify the water body in Classes 1, 2 and 3, although, some values are above the standard established by current legislation, it is observed that the average presented resulted as acceptable for human consumption, because it presented value below the recommended limit of $500 \mathrm{mg} / \mathrm{L}$.

Therefore, the behavior of total solids is similar to turbidity, since both variables are related, and may have presented high values due to the higher concentration of organic matter presented during rainy seasons (BUZELLI; CUNHA-SANTINO, 2013). Salinity is the measure of the total concentration of dissolved ions in water, influenced by natural soil conditions, the regional climate and anthropic, being considered one of the main causes of water quality problems for irrigation purposes (PALÁCIO et al., 2011; QUESADO JÚNIOR et al., 2008).

The average Salinity analytical results for the investigated waters was $0.128 \mathrm{ppt}$ (Table 3 ), but in the rural community Moacir Lucena, analysis 02 (Row 151 and Column 10, Table 3) presented a value of 0.900 ppt. Similar result was obtained by Quesado Júnior et al. (2008) who obtained an average of 0.85 ppt, minimum of 0.01 and maximum of 2.34 ppt. The Conama Resolution 357/2005 and the Ordinance No. 2,914 / 2011 do not assign reference values for salinity in relation to potability, but according to this Resolution, the values presented in the analysis according to the average obtained are classified as freshwater, which are classified by Oliveira et al. (2017) as good for irrigation practices, once they present few restrictions of use, and low risk of developing salinity problems (OLIVEIRA et al., 2017). Thus, regarding salinity, the investigated water samples are related as compatible with the most demanding uses (PESSÔA, 2013).

The values obtained for total coliforms - C. Totals averaged $149.266 \mathrm{CFU} / 100 \mathrm{~mL}$ (Table 3), with values of at least $100.0 \mathrm{CFU} / 100 \mathrm{~mL}$, as the rural communities of Soledade, analysis 01 (Row 63 and Column 11, Table 3); Soledade, analysis 02 (Row 64 and Column 11, from Table 3); Soledade, analysis 04 (Row 66 and Column 11, from Table 3); and Soledade, analysis 08 (Row 70 and Column 11, of Table 3). Regarding the values of thermotolerant coliforms of Escherichia coli - E. coli type, it was obtained an average of $65,910 \mathrm{CFU} / 100 \mathrm{~mL}$ (Table 3), with values of at least $34.0 \mathrm{CFU} / 100 \mathrm{~mL}$, in the rural community of Soledade, analysis 43 (Row 105 and Column 12 of Table 3. In similar studies by Bortoli et al. (2018), it was also observed determination of total coliforms in $62.5 \%$ of the sources used for human consumption in rural properties, and the presence of $\mathrm{E}$. coli in $31.7 \%$, being inappropriate for human consumption.

So, it is possible to indicate the pollution and water contamination, since according to Ordinance MS 2914/2011 should be considered the absence of total coliforms and E. coli thermotolerant coliforms in water intended for human consumption. This representation is recurrent in rural areas and it is 
worrying, since, according to Bortoli et al. (2018), the amount of coliforms present in the analyzed water samples may be related to the inadequate management of animal waste and the infiltration of pits, which compromise the groundwater, making the structural improvement of water supply important, especially in the regarding sanitation measures, proper storage in homes and measures for disinfection (CAVALCANTE, 2014).

Table 3 | Descriptive statistics of the physicochemical and biological parameters of water samples from rural communities of Chapada do Apodi-RN

\begin{tabular}{|c|c|c|c|c|c|c|c|c|c|c|c|}
\hline Sample & $\begin{array}{l}\text { Temp } \\
\left({ }^{\circ} \mathrm{C}\right)\end{array}$ & $\mathrm{pH}$ & $\begin{array}{l}\text { ORP } \\
(\mathrm{mV})\end{array}$ & $\begin{array}{c}\text { EC } \\
(\mu \mathrm{S} / \mathrm{cm})\end{array}$ & $\begin{array}{l}\text { Turbidity } \\
\text { (NTU) }\end{array}$ & $\begin{array}{c}\text { OD } \\
\text { (mg/L) }\end{array}$ & OD (\%) & $\begin{array}{l}\text { Solids Total } \\
\text { Dissolved } \\
\text { (mg/L) }\end{array}$ & Salinity (ppt) & $\begin{array}{c}\text { Total } \\
\text { coliforms } \\
\text { (UFC/100 } \\
\mathrm{mL}) \\
\end{array}$ & $\begin{array}{c}\text { E. coli } \\
\text { (UFC/100 } \\
\mathrm{mL})\end{array}$ \\
\hline Algodão 01 & 29,920 & 4,950 & 300,000 & 233,000 & 0,000 & 11,790 & 153,200 & 151,000 & 0,100 & 101,000 & 71,000 \\
\hline Aroeira Verde 01 & 32,000 & 6,700 & 240,000 & 178,000 & 0,100 & 9,000 & 118,200 & 910,000 & 0,200 & 103,000 & 73,000 \\
\hline B. do Tubarão 01 & 29,300 & 5,360 & 285,000 & 843,000 & 0,000 & 9,730 & 128,200 & 548,000 & 0,400 & 107,000 & 77,000 \\
\hline Campinas 01 & 28,320 & 5,660 & 313,000 & 138,000 & 0,000 & 10,320 & 133,800 & 90,000 & 0,100 & 109,000 & 79,000 \\
\hline Canto de Vara 01 & 27,180 & 5,910 & 319,000 & 278,000 & 4,400 & 13,330 & 170,800 & 180,000 & 0,100 & 110,000 & 76,000 \\
\hline Canto de Vara 02 & 25,800 & 6,190 & 324,000 & 141,000 & 84,400 & 9,350 & 118,500 & 85,000 & 0,100 & 102,000 & 82,000 \\
\hline Carrasco 01 & 28,320 & 5,660 & 313,000 & 138,000 & 0,000 & 10,320 & 133,800 & 90,000 & 0,100 & 104,000 & 84,000 \\
\hline C. dos Bodes 01 & 28,000 & 5,000 & 321,000 & 140,000 & 0,000 & 10,610 & 137,100 & 90,000 & 0,100 & 105,000 & 70,000 \\
\hline Coaçu 01 & 27,680 & 4,340 & 329,000 & 142,000 & 0,000 & 10,900 & 140,400 & 90,000 & 0,100 & 107,821 & 77,000 \\
\hline Nova Soledade 01 & 29,920 & 4,950 & 300,000 & 233,000 & 0,000 & 11,790 & 153,200 & 151,000 & 0,100 & 110,226 & 78,000 \\
\hline Faz. São Luiz 01 & 32,130 & 5,750 & 295,000 & 115,000 & 0,100 & 8,720 & 118,200 & 910,000 & 0,200 & 112,631 & 80,000 \\
\hline Ipoeira 01 & 30,460 & 4,770 & 288,000 & 172,000 & 50,100 & 8,480 & 113,500 & 112,000 & 0,100 & 115,036 & 82,000 \\
\hline João Pedro 01 & 28,000 & 6,000 & 200,000 & 150,000 & 40,000 & 8,000 & 110,000 & 200,000 & 0,100 & 117,440 & 87,000 \\
\hline Lage do Meio 01 & 29,910 & 4,710 & 276,000 & 117,000 & 0,000 & 8,970 & 119,000 & 76,000 & 0,100 & 119,845 & 67,000 \\
\hline Lage do Meio 02 & 28,630 & 4,360 & 252,000 & 0,000 & 19,700 & 10,300 & 134,200 & 0,000 & 0,000 & 122,250 & 68,000 \\
\hline L. do Clem. 01 & 30,460 & 4,770 & 288,000 & 172,000 & 50,100 & 8,480 & 113,500 & 112,000 & 0,100 & 124,655 & 69,000 \\
\hline L. do Clem. 02 & 29,920 & 4,950 & 300,000 & 233,000 & 0,000 & 11,790 & 153,200 & 151,000 & 0,100 & 127,060 & 70,000 \\
\hline L. do Clem. 03 & 29,910 & 4,710 & 276,000 & 117,000 & 0,000 & 8,970 & 119,000 & 76,000 & 0,100 & 129,464 & 71,000 \\
\hline L. do Clem. 04 & 29,547 & 4,750 & 276,000 & 119,000 & 13,400 & 8,237 & 134,067 & 77,000 & 0,100 & 131,869 & 72,000 \\
\hline L. do Clem. 05 & 29,272 & 4,720 & 270,000 & 91,500 & 18,450 & 8,482 & 136,817 & 59,000 & 0,100 & 134,274 & 73,000 \\
\hline L. do Clem. 06 & 29,997 & 4,690 & 264,000 & 64,000 & 13,500 & 8,727 & 139,567 & 141,000 & 0,100 & 136,679 & 74,000 \\
\hline L. do Clem. 07 & 29,722 & 4,660 & 258,000 & 136,500 & 10,550 & 8,972 & 142,317 & 123,000 & 0,100 & 139,083 & 75,000 \\
\hline L. do Clem. 08 & 29,447 & 4,630 & 252,000 & 109,000 & 33,600 & 8,217 & 145,067 & 105,000 & 0,100 & 141,488 & 76,000 \\
\hline L. do Clem. 09 & 29,172 & 4,600 & 246,000 & 118,500 & 10,650 & 8,462 & 147,817 & 113,000 & 0,100 & 143,893 & 77,000 \\
\hline L. do Clem. 10 & 29,897 & 4,570 & 240,000 & 146,000 & 13,700 & 9,707 & 150,567 & 131,000 & 0,100 & 146,298 & 78,000 \\
\hline Laj. da Ovelha 01 & 26,980 & 5,830 & 315,000 & 336,000 & 8,000 & 7,720 & 98,200 & 218,000 & 0,200 & 148,702 & 79,000 \\
\hline Manoplo 01 & 28,000 & 6,000 & 319,000 & 320,000 & 9,000 & 7,000 & 110,000 & 200,000 & 0,100 & 151,107 & 80,000 \\
\hline Morada Nova 01 & 27,000 & 6,700 & 300,000 & 300,000 & 10,000 & 7,720 & 100,000 & 218 & 0,200 & 153,512 & 81,000 \\
\hline Mulungu 01 & 25,800 & 6,190 & 324,000 & 141,000 & 84,400 & 9,350 & 118,500 & 85,000 & 0,100 & 155,917 & 62,000 \\
\hline Mulungu 02 & 25,800 & 6,190 & 324,000 & 141,000 & 84,400 & 9,350 & 118,500 & 85,000 & 0,100 & 158,321 & 63,000 \\
\hline Ostra 01 & 29,447 & 4,630 & 252,000 & 109,000 & 33,600 & 8,217 & 145,067 & 105,000 & 0,100 & 160,726 & 64,000 \\
\hline Pau dos Ferros 01 & 29,340 & 6,119 & 301,333 & 121,278 & 0,150 & 10,110 & 108,000 & 910,000 & 0,000 & 163,131 & 65,000 \\
\hline Pau dos Ferros 02 & 29,547 & 4,750 & 276,000 & 119,000 & 13,400 & 8,237 & 134,067 & 77,000 & 0,100 & 165,536 & 66,000 \\
\hline Pau dos Ferros 03 & 29,172 & 4,600 & 0 & 0 & 0 & 2 & 17 & 0 & 0,100 & 167,940 & 67,000 \\
\hline Pau dos Ferros 04 & 26,740 & 6,140 & 306,000 & 114,000 & 10,000 & 12,890 & 112,600 & 109,000 & 0,100 & 170,345 & 68,000 \\
\hline Pereiro da Raiz 01 & 29,997 & 4,690 & 264,000 & 64,000 & 13,500 & 8,727 & 139,567 & 141,000 & 0,100 & 172,750 & 69,000 \\
\hline Poço Tilon 01 & 29,340 & 6,119 & 301,333 & 121,278 & 0,150 & 10,110 & 108,000 & 910,000 & 0,000 & 175,155 & 70,000 \\
\hline Poço Tilon 02 & 30,300 & 7,198 & 278,000 & 163,833 & 1,900 & 5,270 & 115,000 & 1584,000 & 0,200 & 177,560 & 71,000 \\
\hline Primazia 01 & 29,447 & 4,630 & 252,000 & 109,000 & 33,600 & 8,217 & 145,067 & 105,000 & 0,100 & 179,964 & 72,000 \\
\hline Quadra 01 & 26,740 & 6,140 & 306,000 & 114,000 & 110,000 & 12,890 & 112,600 & 109,000 & 0,100 & 182,369 & 73,000 \\
\hline Quixabeirinha 01 & 29,172 & 4,600 & 246,000 & 118,500 & 10,650 & 8,462 & 147,817 & 113,000 & 0,100 & 184,774 & 74,000 \\
\hline Quixabeirinha 02 & 30,300 & 7,198 & 278,000 & 163,833 & 1,900 & 5,270 & 115,000 & 1584,000 & 0,200 & 187,179 & 75,000 \\
\hline Reis Mago 01 & 29,447 & 4,630 & 252,000 & 109,000 & 33,600 & 8,217 & 145,067 & 105,000 & 0,100 & 189,583 & 76,000 \\
\hline São Francisco 01 & 26,860 & 4,580 & 313,000 & 100,000 & 2,300 & 17,300 & 219,500 & 73,000 & 0,100 & 191,988 & 77,000 \\
\hline
\end{tabular}




\begin{tabular}{|c|c|c|c|c|c|c|c|c|c|c|c|}
\hline nple & $\begin{array}{c}\text { Temp } \\
\left({ }^{\circ} \mathrm{C}\right)\end{array}$ & $\mathrm{pH}$ & $\begin{array}{l}\text { ORP } \\
(\mathrm{mV})\end{array}$ & $\begin{array}{c}E C \\
(\mu \mathrm{S} / \mathrm{cm})\end{array}$ & $\begin{array}{l}\text { Turbidity } \\
\text { (NTU) }\end{array}$ & $\begin{array}{c}\text { OD } \\
(\mathrm{mg} / \mathrm{L})\end{array}$ & OD (\%) & $\begin{array}{l}\text { Solids Total } \\
\text { Dissolved } \\
\text { (mg/L) }\end{array}$ & t) & $\begin{array}{c}\text { Total } \\
\text { coliforms } \\
\text { (UFC/100 } \\
\mathrm{mL}) \\
\end{array}$ & $\begin{array}{c}\text { E. coli } \\
\text { (UFC/100 } \\
\mathrm{mL})\end{array}$ \\
\hline ncisco 02 & ,340 & 6,119 & 301,333 & 121,278 & 0,150 & 10,110 & 108,000 & 910,000 & 0,000 & 194,393 & 45,000 \\
\hline São Francisco 03 & 31,820 & 6,659 & 289,667 & 142,556 & 2,100 & 4,920 & 203,500 & 1147,000 & 0,100 & 196,798 & 47,000 \\
\hline São Francisco 04 & 30,300 & 7,198 & 278,000 & 163,833 & 1,900 & 5,270 & 115,000 & 1584,000 & 0,200 & 199,202 & 49,000 \\
\hline São Francisco 05 & 30,780 & 7,738 & 266,333 & 185,111 & 1,300 & 11,460 & 226,500 & 1421,000 & 0,300 & 201,607 & 51,000 \\
\hline São Francisco 06 & 31,260 & 7,277 & 254,667 & 206,389 & 2,450 & 8,650 & 138,000 & 1258,000 & 0 & 204,012 & 53,000 \\
\hline Serraria 01 & 28,100 & 7,000 & 320,567 & 133,694 & 0,478 & 9,338 & 105,000 & 156,000 & 0,200 & 206,417 & 55,000 \\
\hline Sítio Baixinha 01 & 29,547 & 4,750 & 276,000 & 119,000 & 13,400 & 8,237 & 134,067 & 77,000 & 100 & 208,821 & 57,000 \\
\hline Sítio Cruzeiro 01 & 29,340 & 6,119 & 301,333 & 121,278 & 0,150 & 10,110 & 108,000 & 910,000 & 0,000 & 211,226 & 59,000 \\
\hline Sítio do Góis 01 & 26,860 & 4,580 & 313,000 & 100,000 & 2,300 & 17,300 & 219,500 & 73,000 & 100 & 213,631 & 61,000 \\
\hline Sítio do Góis 02 & 28,770 & 5,140 & 329,000 & 270,000 & 0,000 & 8,800 & 114,000 & 175,000 & 0,100 & 216,036 & 63,000 \\
\hline Sítio do Góis 03 & 28,320 & 5,050 & 260,000 & 100,000 & 0,000 & 8,500 & 100,000 & 62,000 & 00 & 218,440 & 65,000 \\
\hline Sítio do Góis 04 & 29,443 & 5,393 & 247,667 & 156,667 & 533 & 9,733 & 125,000 & 92,000 & 0 & 220,845 & 67,000 \\
\hline Sítio do Góis 05 & 30,173 & 5,628 & 221,167 & 156,667 & 2,683 & 7,667 & 134,750 & 87,000 & 0,100 & 223,250 & 69,000 \\
\hline Sítio do Góis 06 & 30,903 & 5,863 & 194,667 & 156,667 & 3,833 & 8,067 & 164,500 & 81,000 & 0,100 & 225,655 & 71,000 \\
\hline L. Vermelha 01 & 29,410 & 4,950 & 360,000 & 45,000 & 0,000 & 6,740 & 88,800 & 29,000 & 0,000 & 060 & 73,000 \\
\hline Sítio Planalto 01 & 26,580 & 4,890 & 289,000 & 60,000 & 0,000 & 6,610 & 85,000 & 39,000 & 000 & 230,464 & 75,000 \\
\hline Sítio São José 01 & 23,750 & 4,830 & 218,000 & 75,000 & 0,000 & 6,480 & 81,200 & 49,000 & 0,000 & 232,869 & 77,000 \\
\hline Soledade 01 & 28,320 & 5,050 & 260,000 & 100,000 & 0,000 & 8,500 & 100,000 & 62,000 & 0,000 & 100,000 & 79,000 \\
\hline Soledade 02 & 28,820 & 5,780 & 270,000 & 105,000 & 0,000 & 8,800 & 107,000 & 68,000 &, 000 & 00,000 &, 000 \\
\hline Soledade 03 & 28,320 & 5,660 & 313,000 & 138,000 & 0,000 & 10,320 & 133,800 & 90,000 & 0,100 & 106,000 & 83,000 \\
\hline Soledade 04 & 28,000 & 5,000 & 321,000 & 140,000 & 0,000 & 10,610 & 137,100 & 90,000 & 0,100 & 100,000 & 85,000 \\
\hline Soledade 05 & 28,330 & 4,600 & 325,000 & 138,000 & 0,000 & 11,110 & 143,400 & 92,000 & 0,100 & 104,000 & 67,000 \\
\hline Soledade 06 & 32,130 & 5,750 & 295,000 & 115,000 & 0,100 & 8,720 & 118,200 & 910,000 & 0,200 & 108,000 & 7,000 \\
\hline Soledade 07 & 29,350 & 6,000 & 299,000 & 127,000 & 0,100 & 10,390 & 140,000 & 85,000 & 0,2 & 340,000 & 64,000 \\
\hline Soledade 08 & 28,990 & 5,600 & 290,000 & 11,700 & 0,000 & 10,230 & 133,000 & 70,000 & 0,100 & 100,000 & 76,000 \\
\hline Soledade 09 & 30,210 & 5,800 & 270,000 & 104,000 & 0,100 & 8,500 & 115,000 & 56,000 & 0,200 & 120,000 & 79,000 \\
\hline Soledade 10 & 3,000 & 5,795 & 297,500 & 120,861 & 0,092 & 9,898 & 110 & 62, & 0,000 & 102,000 & 78,000 \\
\hline Soledade 11 & 28,050 & 5,860 & 298,267 & 120,944 & 0,103 & 9,941 & 105,000 & 68,000 & 000 & 230,000 & 78,000 \\
\hline Soledade 12 & 28,930 & 5,925 & 299,033 & 121,028 & 0,115 & 9,983 & 108,000 & 90,000 & 0,100 & 203,000 & 75,000 \\
\hline Soledade 13 & 28,760 & 5,990 & 299,800 & 121,111 & 0,127 & 10,025 & 107,000 & 90,000 & 0,100 & 203,000 & 77,000 \\
\hline Soledade 14 & 29,000 & 6,055 & 300,567 & 121,194 & 0,138 & 10,068 & 106,000 & 92 & 0,100 & 300,000 & 52,000 \\
\hline Soled & 30 & 6 & 301 & 121,278 & 0,150 & 10 & 108 & 9 & 0,000 & 340,000 & 44,000 \\
\hline Soledade 16 & 29,330 & 6,184 & 302,100 & 121,361 & 0,162 & 10,152 & 109,000 & 85,000 & 0,000 & 400,000 & 49,000 \\
\hline Soledade 17 & 29,000 & 6,249 & 302,867 & 121,444 & 0,173 & 10,195 & 110,000 & 70,000 & 0,100 & 135,000 & 52,000 \\
\hline 18 & 000 & 4 & 303,633 & 121,528 & 5 & 10,237 & 111, & 0 & 0,100 & 234,000 & 56,333 \\
\hline Soledade 19 & 27,900 & 6,379 & 304,400 & 121,611 & 0,197 & 10,279 & 123,000 & 62,000 & 0,100 & 345,000 & 60,333 \\
\hline Soledade 20 & 28,900 & 6,444 & 305,167 & 121,694 & 0,208 & 10,322 & 111,000 & 68,000 & 0,200 & 146,000 & 64,333 \\
\hline Soledade 21 & 28,700 & 6,508 & 305,933 & 121,778 & 0,220 & 10,364 & 123,000 & 90,000 & 0,200 & 00 & 3 \\
\hline Soledade 22 & 27000 & 6,573 & 306,700 & 121,861 & 0232 & 10,406 & 120,000 & חمת מ & 0100 & 167,000 & 72,333 \\
\hline Soledade 23 & 9,000 & 6,638 & 307,467 & 121,944 & 0,243 & 10,449 & 119,000 & 62,000 & 200 & 157,000 & 76,333 \\
\hline Soledade 24 & 28,900 & 6,703 & 308,233 & 122,028 & 0,255 & 10,491 & 111,000 & 68,000 & 0,000 & 157,000 & 80,333 \\
\hline 25 & 28,000 & 6,768 & 309,000 & 12 & 7 & 10,533 & 00 & 0 & 0,100 & 000 & 84,333 \\
\hline Soledade 26 & 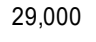 & 6,833 & 320767 & 122,194 & 0278 & 10,576 & 121,000 & 90,000 & 0.100 & 178,000 & 62,000 \\
\hline Soledade 27 & 27,900 & 6,897 & 310,533 & 122,278 & 0,290 & 10,618 & 124,000 & 2,000 & 0,100 & 189,000 & 63,000 \\
\hline Soledade 28 & 29,200 & 6,962 & 311,300 & 122,361 & 0,302 & 10,660 & 124,000 & 910,000 & 0,200 & 190,000 & 64,000 \\
\hline Soledade 29 & 29,100 & 7,027 & 312,067 & 122,444 & 0,313 & 10,703 & 125,000 & 85,000 & 0,000 & 0 & 0 \\
\hline Soledade 30 & 29,000 & 7,092 & 312,833 & 122,528 & 0,325 & 10,745 & 134,000 & 70,000 & 0,000 & 146,000 & 66,000 \\
\hline
\end{tabular}




\begin{tabular}{|c|c|c|c|c|c|c|c|c|c|c|c|}
\hline Sample & $\begin{array}{l}\text { Temp } \\
\left({ }^{\circ} \mathrm{c}\right)\end{array}$ & pH & $\begin{array}{l}\text { ORP } \\
(\mathrm{mV})\end{array}$ & $\begin{array}{c}E C \\
(\mu \mathrm{S} / \mathrm{cm})\end{array}$ & $\begin{array}{l}\text { Turbidity } \\
\text { (NTU) }\end{array}$ & $\begin{array}{c}\mathrm{OD} \\
(\mathrm{mg} / \mathrm{L})\end{array}$ & $\mathrm{OD}(\%)$ & $\begin{array}{l}\text { Solids Total } \\
\text { Dissolved } \\
\text { (mg/L) }\end{array}$ & t) & $\begin{array}{c}\text { Total } \\
\text { coliforms } \\
\text { (UFC/100 } \\
\mathrm{mL}) \\
\end{array}$ & $\begin{array}{c}\text { E. coli } \\
\text { (UFC/100 } \\
\mathrm{mL})\end{array}$ \\
\hline Soledade 31 &, 500 & , 157 & 313,600 & 122,611 & 0,337 & 10,787 & 120,000 & 56,000 & 0,100 & 170,000 & 67,000 \\
\hline Soledade 32 & 3,400 & 7,222 & 314,367 & 122,694 & 0,348 & 10,830 & 120,000 & 62,000 & 100 & 109,000 & 68,000 \\
\hline Soledade 33 & 28,400 & 7,286 & 315,133 & 122,778 & 0,360 & 10,872 & 140,000 & 68,000 & 0,100 & 190,000 & 69,000 \\
\hline Soledade 34 & 28,400 & 7,351 & 315,900 & 122,861 & 0,372 & 10,914 & 140,000 & 90,000 & 0,200 & 191,000 & 70,000 \\
\hline Soledade 35 & 28,500 & 7,416 & 316,667 & 122,944 & 0,383 & 10,957 & 105,000 & 90,000 & 0,200 & 192,000 & 71,000 \\
\hline Soledade 36 & 28,000 & 7,481 & 317,433 & 123,028 & 0,395 & 10,999 & 104,000 & 62,000 & 0,100 & 195,000 & 72,000 \\
\hline Soledade 37 & 29,100 & 7,546 & 318,200 & 123,111 & 0,407 & 11,041 & 106,000 & 68,000 & 0,200 & 140,000 & 73,000 \\
\hline Soledade 38 & 29,000 & 7,611 & 318,967 & 123,194 & 0,418 & 11,084 & 105,000 & 90,000 & 0,100 & 140,000 & 74,000 \\
\hline Soledade 39 & 29,200 & 7,675 & 319,733 & 123,278 & 0,430 & 11,126 & 106,000 & 90,000 & 0,100 & 194,000 & 75,000 \\
\hline Soledade 40 & 29,300 & 7,740 & 320,500 & 123,361 & 0,442 & 11,168 & 104,000 & 92,000 & 0,200 & 195,000 & 76,000 \\
\hline Soledade 41 & 29,200 & 7,805 & 321,267 & 123,444 & 0,453 & 11,211 & 106,000 & 910,000 & 0,200 & 195,000 & 77,000 \\
\hline Soledade 42 & 29,400 & 7,870 & 322,033 & 123,528 & 0,465 & 11,253 & 107,000 & 85,000 & 0,100 & 196,000 & 78,000 \\
\hline Soledade 43 & 29,500 & 7,935 & 322,800 & 123,611 & 0,477 & 11,295 & 107,000 & 70,000 & 0,200 & 197,000 & 34,000 \\
\hline Soledade 44 & 28,100 & 8,000 & 323,567 & 123,694 & 0,488 & 11,338 & 107,000 & 56,000 & 0,400 & 198,000 & 35,000 \\
\hline Soledade 45 & 28,700 & 8,064 & 324,333 & 123,778 & 0,500 & 11,380 & 107,000 & 0,000 & 0,200 & 198,000 & 37,000 \\
\hline Soledade 46 & 28,700 & 8,129 & 325,100 & 123,861 & 0,512 & 11,422 & 108,000 & 0,000 & 0,300 & 199,000 & 39,000 \\
\hline Frei Damião 01 & 29,340 & 6,119 & 301,333 & 121,278 & 0,150 & 10,110 & 108,000 & 910,000 & 0,000 & 110,000 & 40,500 \\
\hline Frei Damião 02 & 29,997 & 4,690 & 264,000 & 64,000 & 13,500 & 8,727 & 139,567 & 141,000 & 0,100 & 110,000 & 42,200 \\
\hline Frei Damião 03 & 28,100 & 7,000 & 320,567 & 133,694 & 0,478 & 9,338 & 105,000 & 156,000 & 0,200 & 102,000 & 43,900 \\
\hline Frei Damião 04 & 32,000 & 6,700 & 240,000 & 178,000 & 0,100 & 9,000 & 118,200 & 910,000 & 0,200 & 102,000 & 45,600 \\
\hline Frei Damião 05 & 26,740 & 6,140 & 306,000 & 114,000 & 110,000 & 12,890 & 112,600 & 109,000 & 0,100 & 103,000 & 47,300 \\
\hline Caiçara 01 & 29,340 & 6,119 & 301,333 & 121,278 & 0,150 & 10,110 & 108,000 & 910,000 & 0,000 & 103,333 & 49,000 \\
\hline Caiçara 02 & 29,447 & 4,630 & 252,000 & 109,000 & 33,600 & 8,217 & 145,067 & 105,000 & 0,100 & 103,833 & 50,700 \\
\hline Caiçara 03 & 29,300 & 7,740 & 320,500 & 123,361 & 0,442 & 11,168 & 104,000 & 92,000 & 0,200 & 104,333 & 52,400 \\
\hline Caiçara 04 & 29,172 & 4,600 & 246,000 & 118,500 & 10,650 & 8,462 & 147,817 & 113,000 & 0,100 & 104,833 & 54,100 \\
\hline Caiçara 05 & 32,000 & 6,700 & 240,000 & 178,000 & 0,100 & 9,000 & 118,200 & 910,000 & 0,200 & 105,333 & 55,800 \\
\hline Caiçara 06 & 29,997 & 4,690 & 264,000 & 64,000 & 13,500 & 8,727 & 139,567 & 141,000 & 0,100 & 105,833 & 57,500 \\
\hline Paul. Canapum 01 & 29,340 & 6,119 & 301,333 & 121,278 & 0,150 & 10,110 & 108,000 & 910,000 & 0,000 & 106,333 & 59,200 \\
\hline Paul. Canapum 02 & 32,000 & 6,700 & 240,000 & 178,000 & 0,100 & 9,000 & 118,200 & 910,000 & 0,200 & 106,833 & 60,900 \\
\hline Paul. Canapum 03 & 29,547 & 4,750 & 276,000 & 119,000 & 13,400 & 8,237 & 134,067 & 77,000 & 0,100 & 107,333 & 62,600 \\
\hline Paul. Canapum 04 & 29,172 & 4,600 & 246,000 & 118,500 & 10,650 & 8,462 & 147,817 & 113,000 & 100 & 107,833 & 64,300 \\
\hline Paul. Canapum 05 & 29,997 & 4,690 & 264,000 & 64,000 & 13,500 & 8,727 & 139,567 & 141,000 & 0,100 & 108,333 & 66,000 \\
\hline Paul. Canapum 06 & 29,997 & 4,690 & 264,000 & 64,000 & 13,500 & 8,727 & 139,567 & 141,000 & 0,100 & 108,833 & 67,700 \\
\hline São Bento 01 & 29,340 & 6,119 & 301,333 & 121,278 & 0,150 & 10,110 & 108,000 & 910,000 & 0,000 & 109,333 & 69,400 \\
\hline São Bento 02 & 32,850 & 6,710 & 383,000 & 109,000 & 0,000 & 10,850 & 149,900 & 71,000 & 0,000 & 109,833 & 1,100 \\
\hline São Bento 03 & 29,447 & 4,630 & 252,000 & 109,000 & 33,600 & 8,217 & 145,067 & 105,000 & 0,100 & 110,333 & 72,800 \\
\hline São Bento 04 & 29,172 & 4,600 & 246,000 & 118,500 & 10,650 & 8,462 & 147,817 & 113,000 & 0 & 110,833 & 74,500 \\
\hline Tab. Grande 01 & 28,500 & 5,000 & 332,000 & 267,000 & 0,000 & 0 & 104,000 & 170 & 0 & 111,333 & 76,200 \\
\hline Tab. Grande 02 & 28,100 & 7,000 & 320,567 & 133,694 & 0,478 & 9,338 & 105,000 & 156,000 & 0,200 & 111,833 & 77,900 \\
\hline Tab. Grande 03 & 27,700 & 8,999 & 309,133 & 0,389 & 0,957 & 8,375 & 106,000 & 142,000 & 0,300 & 112,333 & 41,000 \\
\hline Tab. Grande 04 & 27,300 & 7,999 & 297,700 & 132,917 & 0,435 & 8,413 & 107,000 & 128,000 & 0,400 & 112,833 & 42,000 \\
\hline Tab. Grande 05 & 26,900 & 7,998 & 286,267 & 266,222 & 0,913 & 8,451 & 108,000 & 114,000 & 0,500 & 333 & 43,000 \\
\hline Tab. Grande 06 & 26,500 & 7,998 & 274,833 & 299,528 & 0,392 & 8,488 & 109,000 & 100,000 & 0600 & 13,833 & 44,000 \\
\hline Sítio do Góis 01 & 28,770 & 5,140 & 329,000 & 270,000 & 0,000 & 8,800 & 114,000 & 175,000 & 0,100 & 114,333 & 45,000 \\
\hline Sítio do Góis 02 & 29,260 & 37 & 339,433 & 282,361 & 478 & 929 & 116,333 & 191,000 & 000 & 114,833 & 46,000 \\
\hline Sítio do Góis 03 & 30,195 & 6,758 & 360,800 & 284,250 & 0,935 & 9,104 & 119,333 & 221,000 & 0,200 & 115,333 & 47,000 \\
\hline Sítio do Góis 04 & 30,130 & 6,329 & 302,167 & 286,139 & 0,392 & 9,278 & 122,333 & 252,000 & 0,400 & 115,833 & 48,000 \\
\hline Sítio do Góis 05 & 30,065 & 6,101 & 63,533 & 288,028 & 0,848 & 9,453 & 125,333 & 282,000 & 0,600 & 116 & 49, \\
\hline Sítio do Góis 06 & 30,000 & 6,530 & 324,900 & 289,917 & 2,305 & 9,628 & 128,333 & 313,000 & 0,800 & 116,833 & 50,000 \\
\hline
\end{tabular}




\begin{tabular}{|c|c|c|c|c|c|c|c|c|c|c|c|}
\hline Sample & $\begin{array}{c}\text { Temp } \\
\left({ }^{\circ} \mathrm{C}\right)\end{array}$ & $\mathrm{pH}$ & $\begin{array}{l}\text { ORP } \\
(\mathrm{mV})\end{array}$ & $\begin{array}{c}\text { EC } \\
(\mu \mathrm{S} / \mathrm{cm})\end{array}$ & $\begin{array}{l}\text { Turbidity } \\
\text { (NTU) }\end{array}$ & $\begin{array}{c}\text { OD } \\
\text { (mg/L) }\end{array}$ & OD (\%) & $\begin{array}{l}\text { Solids Total } \\
\text { Dissolved } \\
\text { (mg/L) }\end{array}$ & Salinity (ppt) & $\begin{array}{c}\text { Total } \\
\text { coliforms } \\
\text { (UFC/100 } \\
\mathrm{mL} \text { ) }\end{array}$ & $\begin{array}{c}\text { E. coli } \\
\text { (UFC/100 } \\
\mathrm{mL} \text { ) }\end{array}$ \\
\hline Sítio do Góis 06 & 30,000 & 6,530 & 324,900 & 289,917 & 2,305 & 9,628 & 128,333 & 313,000 & 0,800 & 116,833 & 50,000 \\
\hline Vila Nova 01 & 29,547 & 4,750 & 276,000 & 119,000 & 13,400 & 8,237 & 134,067 & 77,000 & 0,100 & 117,333 & 51,000 \\
\hline Aur. da Serra 01 & 29,340 & 6,119 & 301,333 & 121,278 & 0,150 & 10,110 & 108,000 & 910,000 & 0,000 & 117,833 & 52,000 \\
\hline Aur. da Serra 02 & 29,997 & 4,690 & 264,000 & 64,000 & 13,500 & 8,727 & 139,567 & 141,000 & 0,100 & 118,333 & 53,000 \\
\hline Aur. da Serra 03 & 32,850 & 6,710 & 383,000 & 109,000 & 0,000 & 10,850 & 149,900 & 71,000 & 0,000 & 118,833 & 54,000 \\
\hline Aur. da Serra 04 & 30,300 & 7,198 & 278,000 & 163,833 & 1,900 & 5,270 & 115,000 & 1584,000 & 0,200 & 119,333 & 55,000 \\
\hline Aur. da Serra 05 & 32,000 & 6,700 & 240,000 & 178,000 & 0,100 & 9,000 & 118,200 & 910,000 & 0,200 & 119,833 & 56,000 \\
\hline Aur. da Serra 06 & 28,100 & 7,000 & 320,567 & 133,694 & 0,478 & 9,338 & 105,000 & 156,000 & 0,200 & 120,333 & 57,000 \\
\hline Aur. da Serra 07 & 29,547 & 4,750 & 276,000 & 119,000 & 13,400 & 8,237 & 134,067 & 77,000 & 0,100 & 120,833 & 58,000 \\
\hline Moacir Lucena 01 & 27,620 & 4,700 & 340,000 & 0,000 & 261,000 & 10,100 & 128,400 & 0,000 & 0,000 & 121,333 & 59,000 \\
\hline Moacir Lucena 02 & 32,010 & 7,050 & 169,000 & 176,000 & 0,000 & 8,060 & 110,500 & 1130,000 & 0,900 & 121,833 & 60,000 \\
\hline Moacir Lucena 03 & 28,880 & 4,960 & 300,000 & 17,600 & 0,000 & 9,120 & 110,000 & 114,000 & 0,100 & 122,333 & 61,000 \\
\hline Milagre 01 & 28,630 & 4,360 & 252,000 & 0,000 & 19,700 & 10,300 & 134,200 & 0,000 & 0,000 & 122,833 & 62,000 \\
\hline Milagre 02 & 28,130 & 4,810 & 313,000 & 85,000 & 0,100 & 19,740 & 255,300 & 57,000 & 0,000 & 123,333 & 63,000 \\
\hline Milagre 03 & 26,340 & 4,740 & 310,000 & 96,000 & 0,000 & 7,930 & 100,000 & 62,000 & 0,000 & 123,833 & 64,000 \\
\hline Milagre 04 & 27,410 & 5,017 & 349,667 & 156,333 & 13,100 & 10,287 & 128,967 & 102,000 & 0,000 & 124,333 & 65,000 \\
\hline Paraíso 01 & 28,000 & 4,120 & 300,000 & 153,000 & 0,000 & 8,000 & 110,000 & 116,000 & 0,100 & 124,833 & 66,000 \\
\hline Paraíso 02 & 31,890 & 4,690 & 345,000 & 172,000 & 0,000 & 8,000 & 108,000 & 112,000 & 0,100 & 125,333 & 67,000 \\
\hline Paraíso 03 & 30,380 & 4,840 & 336,000 & 180,000 & 0,000 & 9,510 & 126,200 & 116,000 & 0,100 & 125,833 & 68,000 \\
\hline Paraíso 04 & 30,290 & 4,740 & 339,000 & 181,000 & 0,000 & 9,700 & 128,000 & 117,000 & 0,100 & 126,333 & 69,000 \\
\hline Lage do Meio 01 & 28,870 & 4,450 & 315,000 & 178,000 & 0,000 & 8,540 & 111,700 & 116,000 & 0,100 & 126,833 & 70,000 \\
\hline Lage do Meio 02 & 32,850 & 6,710 & 383,000 & 109,000 & 0,000 & 10,850 & 149,900 & 71,000 & 0,000 & 127,333 & 71,000 \\
\hline Lage do Meio 03 & 30,300 & 7,198 & 278,000 & 163,833 & 1,900 & 5,270 & 115,000 & 1584,000 & 0,200 & 127,833 & 72,000 \\
\hline São Manoel 01 & 29,172 & 4,600 & 246,000 & 118,500 & 10,650 & 8,462 & 147,817 & 113,000 & 0,100 & 128,333 & 73,000 \\
\hline São Manoel 02 & 32,000 & 6,700 & 240,000 & 178,000 & 0,100 & 9,000 & 118,200 & 910,000 & 0,200 & 128,833 & 74,000 \\
\hline São Manoel 03 & 29,340 & 6,119 & 301,333 & 121,278 & 0,150 & 10,110 & 108,000 & 910,000 & 0,000 & 129,333 & 75,000 \\
\hline N. Des coberta 01 & 28,380 & 5,820 & 360,000 & 168,000 & 0,000 & 16,330 & 212,000 & 109,000 & 0,100 & 129,833 & 76,000 \\
\hline N. Descoberta 02 & 25,560 & 4,480 & 333,000 & 77,000 & 105,000 & 17,720 & 99,700 & 0,000 & 0,000 & 130,333 & 77,000 \\
\hline N. Descoberta 03 & 26,740 & 6,140 & 306,000 & 114,000 & 110,000 & 12,890 & 112,600 & 109,000 & 0,100 & 130,833 & 78,000 \\
\hline N. Descoberta 04 & 29,920 & 6,800 & 279,000 & 105,000 & 115,000 & 19,500 & 124,900 & 218,000 & 0,200 & 131,333 & 79,000 \\
\hline N. Descoberta 05 & 27,100 & 6,460 & 252,000 & 196,000 & 420,000 & 18,110 & 237,200 & 327,000 & 0,300 & 131,833 & 80,000 \\
\hline A. Palmares 01 & 32,850 & 6,710 & 383,000 & 109,000 & 0,000 & 10,850 & 149,900 & 71,000 & 0,000 & 132,333 & 81,000 \\
\hline A. Palmares 02 & 32,950 & 4,290 & 348,000 & 76,000 & 56,400 & 7,120 & 98,100 & 52,000 & 0,000 & 132,833 & 82,000 \\
\hline A. Palmares 03 & 33,050 & 4,870 & 313,000 & 43,000 & 17,800 & 8,390 & 146,300 & 33,000 & 0,000 & 133,333 & 83,000 \\
\hline Casulo 01 & 29,172 & 4,600 & 246,000 & 118,500 & 10,650 & 8,462 & 147,817 & 113,000 & 0,100 & 133,833 & 84,000 \\
\hline Casulo 02 & 26,740 & 6,140 & 306,000 & 114,000 & 11,000 & 12,890 & 112,600 & 109,000 & 0,100 & 134,333 & 85,000 \\
\hline Letícia 01 & 28,100 & 7,000 & 320,567 & 13 & 0,478 & 9,338 & 105,000 & 156 & 0,200 & 134,833 & 86,000 \\
\hline Letícia 02 & 29,172 & 4,600 & 246,000 & 118,500 & 10,650 & 8,462 & 147,817 & 113,000 & 0,100 & 135,333 & 87,000 \\
\hline Imóvel Algodão 01 & 32,000 & 6,700 & 240,000 & 178,000 & 0,100 & 9,000 & 118,200 & 910,000 & 0,200 & 135,833 & 63,000 \\
\hline Imóvel Algodão 02 & 32,850 & 6,710 & 383,000 & 109,000 & 0,000 & 10,850 & 149,900 & 71,000 & 0,000 & 136,333 & 62,000 \\
\hline Baixa Verde 01 & 29,340 & 6,119 & 301,333 & 121,278 & 0,150 & 10,110 & 108,000 & 910,000 & 0,000 & 136,833 & 61,000 \\
\hline Baixa Verde 02 & 26,740 & 6,140 & 306,000 & 114,000 & 10,000 & 12,890 & 112,600 & 109,000 & 0,100 & 137,333 & 60,000 \\
\hline Baixa Verde 03 & 29,997 & 4,690 & 264,000 & 64,000 & 13,500 & 8,727 & 139,567 & 141,000 & 0,100 & 137,833 & 59,000 \\
\hline Baixa Verde 04 & 30,300 & 7,198 & 278,000 & 163,833 & 1,900 & 5,270 & 115,000 & 1584,000 & 0,200 & 138,333 & 58,000 \\
\hline Baixa Verde 05 & 28,100 & 7,000 & 320,567 & 133,694 & 0,478 & 9,338 & 105,000 & 156,000 & 0,200 & 138,833 & 57,000 \\
\hline Baixa Verde 06 & 29,172 & 4,600 & 246,000 & 118,500 & 10,650 & 8,462 & 147,817 & 113,000 & 0,100 & 139,333 & 56,000 \\
\hline Cruzeiro 01 & 28,000 & 6,000 & 200,000 & 150,000 & 10,000 & 8,000 & 110,000 & 200,000 & 0,100 & 139,833 & 55,000 \\
\hline Average & 29,148 & 5,924 & 292,566 & 138,565 & 12,998 & 9,750 & 126,013 & 278,866 & 0,128 & 149,266 & 65,910 \\
\hline Median & 29,172 & 6,055 & 301,333 & 122,028 & 0,442 & 9,350 & 118,500 & 109,000 & 0,100 & 132,833 & 68,000 \\
\hline Standard deviation & 1,558 & 1,093 & 39,972 & 77,907 & 41,244 & 2,242 & 25,745 & 388,809 & 0,127 & 49,229 & 12,107 \\
\hline Minimum & 23,750 & 4,120 & 63,533 & 0,000 & 0,000 & 4,920 & 81,200 & 0,000 & 0,000 & 100,000 & 34,000 \\
\hline Maximum & 33,050 & 8,999 & 383,000 & 843,000 & 420,000 & 19,740 & 255,300 & 1584,000 & 0,900 & 400,000 & 87,000 \\
\hline
\end{tabular}

Source: Authors (2019). 
According to the table presented, the results of the physicochemical (temperature, $\mathrm{pH}$, redox potential, electrical conductivity, turbidity, dissolved oxygen, total residue and salinity) and biological variables ( $E$. coli Thermotolerant Coliforms) of the drinking water samples in the rural communities of Chapada do Apodi/RN showed varying behavior (minimum and maximum) (Figure 3).
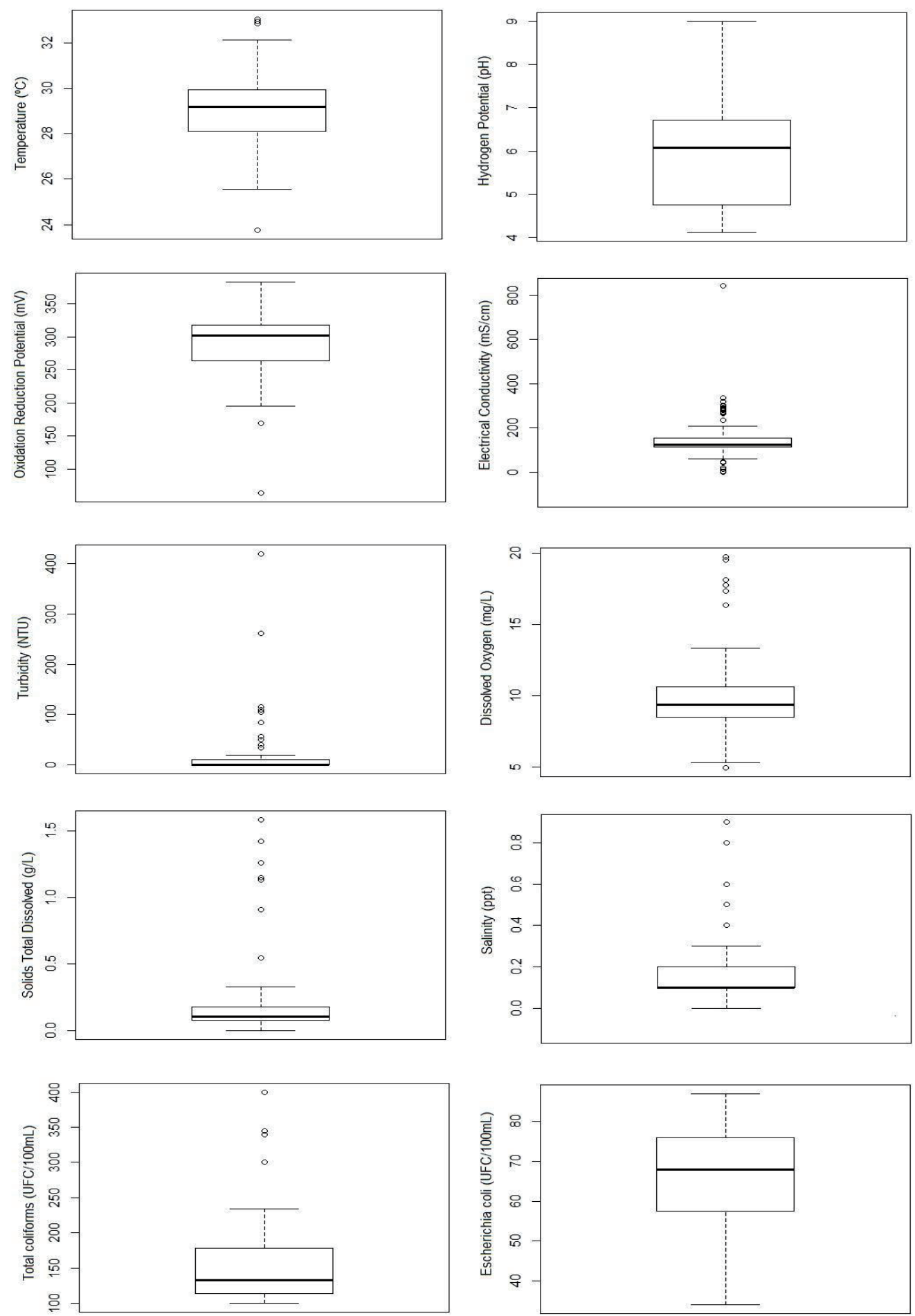

Figure 3 | Boxplot graphs of the physicochemical and biological parameters of the investigated samples.

Source: Authors (2019).

Through these data, it is possible to compare and evaluate the intensity of the relation between the physicochemical parameter values obtained in water samples in the residential reservoirs of the rural 
communities under this study, using the Spearman correlation matrix, which allows observing the influence between water characteristics (Table 4).

It can be observed that there is a negative correlation between the temperature and total coliforms variables (Table 4, row 10, column 1). It happens as a result of the high temperature influencing the presence of total coliforms in the water samples since it interferes with the life cycle of bacteria and parasites. Thus, the values analyzed for total and thermotolerant coliforms of type E. coli, were above the recommended by legislation, this is explained by contaminating anthropogenic sources near the points that supply the rural communities of Chapada do Apodi/RN.

The EC parameter showed positive correlations between $\mathrm{pH}$ (Table 4, row 2, column 4) and STD (Table 4 , row 08 , column 2), this is due to the relation of EC with the presence of dissolved ions in water. The EC parameter does not pose any risk to human health, but for its value, the concentration of STD can be calculated. Which offers risk because, when in excess, it makes the water unpleasant to the taste, corroding pipes and, its consumption may cause the accumulation of salts in the bloodstream (SANTOS; MOHR, 2013).

A positive ORP value was also found when associated with $\mathrm{pH}$ (Table 4, row 2, column 3) and OD (Table 4 , row 6 , column 3), being possible when there is a larger amount of organic solid within the system leading the $\mathrm{pH}$ to be more acid, increasing the oxygen consumption (BRAZ et al., 2012).

The results also showed a positive correlation between turbidity and dissolved oxygen (Table 4, row 6, column 5), since the turbidity is the main physical factor which affects water for the excess of segments, and may influence gas consumption like dissolved oxygen (TUNDISI, 2005).

Finally, a relation between STD variables and temperature was found (Table 4, row 1, column 8). Seeing that, the particulate matter when reaches waterbody through runoff, can influence its temperature, once when in high concentration, the solids may absorb a large amount of heat (MALHEIROS et al., 2012).

Table 4 | Spearman correlation matrix between the physicochemical parameters of the rural communities of Chapada do Apodi - RN.

\begin{tabular}{|c|c|c|c|c|c|c|c|c|c|c|c|}
\hline & Temp & $\mathrm{pH}$ & ORP & CE & Turb & $O D$ & OD (\%) & STD & Salin & C. Totais & E. coli \\
\hline Temp & 1,0000 & & & & & & & & & & \\
\hline $\mathrm{pH}$ & 0,0159 & 1,0000 & & & & & & & & & \\
\hline ORP & $-0,1045$ & 0,2277 & 1,0000 & & & & & & & & \\
\hline EC & 0,0284 & 0,1259 & $-0,0264$ & 1,0000 & & & & & & & \\
\hline Turb & $-0,2316$ & $-0,1104$ & $-0,0344$ & $-0,0819$ & 1,0000 & & & & & & \\
\hline$O D$ & $-0,2791$ & 0,0919 & 0,3061 & $-0,0706$ & 0,3152 & 1,0000 & & & & & \\
\hline OD (\%) & 0,1467 & $-0,2859$ & $-0,0929$ & $-0,0101$ & 0,2209 & 0,4000 & 1,0000 & & & & \\
\hline STD & 0,3849 & 0,3233 & $-0,2007$ & 0,1813 & $-0,1091$ & $-0,2855$ & $-0,0598$ & 1,0000 & & & \\
\hline Salin & 0,0707 & 0,4215 & $-0,2888$ & 0,4237 & $-0,0138$ & $-0,0798$ & $-0,0342$ & 0,2082 & 1,0000 & & \\
\hline $\begin{array}{c}\text { c. } \\
\text { Totals }\end{array}$ & $-0,1224$ & 0,1710 & 0,0319 & $-0,1050$ & $-0,0948$ & 0,0196 & $-0,0729$ & 0,0036 & $-0,0930$ & 1,0000 & \\
\hline E. coli & $-0,0774$ & $-0,3032$ & 0,0154 & $-0,0374$ & 0,1219 & 0,0904 & 0,0801 & $-0,1970$ & $-0,2817$ & $-0,1088$ & 1,0000 \\
\hline
\end{tabular}


Observing such context of environmental perception and water quality results, there are deficiencies, irregularities and a lack of an adequate water supply system in the rural communities of Chapada do Apodi/RN, reflecting directly on access, distribution, and quality of water for human consumption.

\section{FINAL CONSIDERATIONS}

The water supply system in the rural communities of Chapada do Apodi/RN occurs through the use of water tanks and wells, with irregularities in the form of water storage and treatment applied before human consumption. Despite these irregularities, this feature has been used for a variety of purposes, including home use, irrigation, and animal use.

The form of water use in Chapada do Apodi/RN contributes to a panorama of risks to human health, as $72 \%$ of the population consumes water without any previous treatment. The risk is evidenced by the occurrence of symptoms and diseases of water transmission cited by the population, such as diarrhea, fever, and dengue.

In the evaluation of water quality, only the parameters of electrical conductivity, turbidity, total residue, and dissolved oxygen showed acceptable standards for human consumption according to the average values presented by Conama Resolution 357/2005 and Ordinance MS No. 2.914 / 2011. In contrast, the results found for the $\mathrm{pH}$ parameters, total coliforms, and $\mathrm{E}$. coli thermotolerant coliforms presented disagreement according to current legislation. Salinity values presented were, according to Conama Resolution 357/2005, within the limit established for freshwater bodies intended for human consumption.

The results obtained considered the infrastructure conditions of water supply systems, as well as the physical-chemical and biological parameters of water intended for human consumption without previous treatment as unsatisfactory. Thus, it is necessary to adopt preventive measures with the residents of rural communities, prioritizing the preservation of water quality and its treatment, to minimize the risks of water-borne diseases.

In this context, further studies on the quality of water with physical-chemical, biological, heavy metals and pesticides parameters, present in water intended for human consumption, during rainy and drought periods, and its possible relationship with agro-industrial and agricultural activities are recommended; aiming to correlate the results obtained from these parameters in the different interferences of the quality of life of traditional rural communities.

\section{REFERENCES}

AMARAL, L. A. do. et al. Água de consumo humano como fator de risco à saúde em propriedades rurais. Revista Saúde Pública, São Paulo, v. 37, n. 4, p. 510- 514, 2003.

APHA - AWWA - WPCF. Standart methods for the examination of water and wastewater. $19^{\text {th }}$ edition. Wasghington D.C. American Public Health Association.1995. 953p.

ARAÚJO, G. F. R. et al. Qualidade físico-química e microbiológica da água para o consumo humano e a relação com a saúde: estudo em uma comunidade rural no estado de São Paulo. O Mundo da Saúde. São Paulo, v. 35, n. 1, p. 98-104, 2011.

BABBIE, E. Métodos de Pesquisas de Survey. Belo Horizonte: UFMG, 2001.

BERTOSSI, A. P. A. et al. Seleção e agrupamento de indicadores da qualidade de águas utilizando estatística multivariada. Revista Semina: Ciências Agrárias, v. 34, n. 5, p. 2025-2036, 2013. 
BHATTI, M. T.; LATIF, M. Assessment of water quality of a river using an indexing approach during the low-flow season. Irrigation and Drainage, n. 60, p. $103-114,2011$.

BOLFARINE, H.; BUSSAB, W. O. Elementos de amostragem. São Paulo: Editora Blücher, 2005.

BORTOLI, J. de. et al. Avaliação microbiológica da água em propriedades rurais produtoras de leite localizadas no Rio Grande do Sul, Brasil. Revista Brasileira de Higiene e Sanidade Animal, v. 12, n. 1, p. 39, 2018.

BRASIL. Ministério da Saúde. Portaria no 2.914 de 12 de dezembro de 2011. Dispõe sobre os procedimentos e responsabilidades relativos ao controle e vigilância da qualidade da água para consumo humano e seu padrão de potabilidade. Diário Oficial (da) República Federativa do Brasil, Brasília, DF, 2011.

BRAZ, L. et al. Influência de características físico-químicas da água no transporte de metano para a atmosfera na Lagoa Rodrigo de Freitas, RJ. Revista Ambiente \& Agua, Taubaté, v. 7, n. 3, p. 99-112, 2012.

BRUM, B. R. et al. Qualidade das águas de poços rasos em área com déficit de saneamento básico em Cuiabá, MT: avaliação microbiológica, físico-química e fatores de risco à saúde. Holos, v. 2, n. 32, p. 179-188, 2016.

BUZELLI, G. M.; CUNHA-SANTINO, M. B. Análise e diagnóstico da qualidade da água e estado trófico do reservatório de Barra Bonita (SP). Revista Ambiente \& Água, Taubaté, v. 8, n. 1, p. 186-205, 2013.

CARNEIRO, F. F.; RIGOTTO, R. M.; PIGNATI, W. Frutas, cereais e carne do Sul: agrotóxicos e conflitos ambientais no agronegócio no Brasil. Raega: o espaço geográfico em análise, Curitiba, v. 17, p.10-30, 2012.

CASALI, C. A. Qualidade da água para consumo humano ofertada em escolas e comunidades rurais da região central do Rio Grande do Sul. 2008. 173 f. Dissertação (Mestrado em Ciências do Solo) - Programa de PósGraduação em Ciências do Solo, Universidade Federal de Santa Maria, Santa Maria, 2008.

CAVALCANTE, R. B. L. Ocorrência de Escherichia coli em fontes de água e pontos de consumo em uma comunidade rural. Revista Ambiente \& Água, v. 9, n. 3, 2014.

COMPANHIA AMBIENTAL DO ESTADO DE SÃO PAULO. Variáveis da qualidade de água. 2010. Disponível em: <http:// www.cetesb.sp.gov.br/agua/aguas-superficiais/109-variaveis-de-qualidade-das-aguas>. Acesso em: 17 abr. 2019.

CONSELHO NACIONAL DO MEIO AMBIENTE. Ministério do Meio Ambiente. Resolução no 357 de 17 de março de 2005. Dispõe sobre a classificação dos corpos de água e diretrizes ambientais para o seu enquadramento, bem como estabelece as condições e padrões de lançamento de efluentes. Diário Oficial (da) República Federativa do Brasil, Brasília, DF, 2005.

DEL RIO, V.; OLIVEIRA, L. (Org.). Percepção ambiental: a experiência brasileira. São Paulo: Studio Nobel; São Carlos, SP: Universidade Federal de São Carlos, 1996.

DERÍSIO, J. C. Introdução ao Controle de Poluição Ambiental. 4. ed. São Paulo: Signus, 2012.

ESTEVES, F. A. Fundamentos de Limnologia. 3. ed. Rio de Janeiro: Interciência, 2011. 602 p.

FIORUCCI, A. R.; BENEDETTI FILHO, E. A. A importância do oxigênio dissolvido em ecossistemas aquáticos. Química Nova na Escola, São Paulo, v. 22, p. 10-16, 2005.

FONSECA, J. J. S. Metodologia da pesquisa científica. Fortaleza: UECE, 2002. Apostila.

GIATTI, L. L. Reflexões sobre Água de Abastecimento e Saúde Pública: um estudo de caso na Amazônia Brasileira. Saúde e Sociedade, v. 16, n. 1, p. 134-144, 2007. 
GIL, A. C. Como elaborar projetos de pesquisa. 6. ed. São Paulo: Atlas, 2008.

LEMOS, C. A. Qualidade da água de uma bacia hidrográfica inserida na Reserva da Biosfera da Mata Atlântica, Maquiné, Rio Grande do Sul, Brasil. 98 f. 2003. Dissertação (Mestrado em Ecologia) - Instituto de Biociências, UFRGS, Porto Alegre, 2003.

LIBÂNIO, M. Fundamentos de qualidade e tratamento de água. São Paulo: Editora Átomo, 2005.

MACHADO, S. R. et al. Qualidade físico-química e bacteriológica da água que abastece o assentamento Canudos, Município de Palmeiras de Goiás. Enciclopédia Biosfera, v. 11, p. 3114-3126, 2015.

MALHEIROS, C. H. et al. Qualidade da água de uma represa localizada em área agrícola Campo Verde, MT, Brasil. Revista Ambiente \& Água, Taubaté, v. 7, n. 2, p. 245-262, 2012.

MAROTTA, H.; SANTOS, R. O. dos; ENRICH-PRAST, A. Monitoramento limnológico: um instrumento para a conservação dos recursos hídricos no planejamento e na gestão urbano-ambiental. Revista Ambiente e Sociedade, Campinas, v. 11, n. 1, 2008.

MEDEIROS, A. C.; LIMA, M. O.; GUIMARAES, R. M. Avaliação da qualidade da água de consumo por comunidades ribeirinhas em áreas de exposição a poluentes urbanos e industriais nos municípios de Abaetetuba e Barcarena no estado do Pará, Brasil. Ciência e Saúde Coletiva, v. 21, n. 3, p. 695-708, 2016.

MELAZO, C. G. Percepção ambiental e educação ambiental: uma reflexão sobre as relações interpessoais e ambientais no espaço urbano. Olhares e Trilhas, v. 4, n. 6, p. 45-51, 2005.

MORAIS, G. F. O. et al. Manejo, aspectos sanitários e qualidade da água de cisternas em comunidades do semiárido sergipano. Gaia Scientia, v. 11, p. 129-151, 2017.

NOGUEIRA, F. F.; COSTA, I. A.; PEREIRA, U. A. Análise de Parâmetros Físico-Químicos da Água e do Uso e Ocupação do Solo na Sub-bacia do Córrego da Água Branca no Município de Nerópolis - Goiás. 2015. Trabalho de Conclusão de Curso (Bacharelado em Engenharia Ambiental e Sanitária) - Universidade Federal de Goiás, Goiânia, 2015.

OLIVEIRA, A. M. et al. Avaliação físico-química das águas do processo de dessalinização de poços salobros e salinos em comunidades rurais do oeste potiguar. Águas Subterrâneas, São Paulo, v. 31, p. 58-73, 2017.

PALÁCIO, H. A. Q. et al. Similaridade e fatores determinantes na salinidade das águas superficiais do Ceará, por técnicas multivariadas. Revista Brasileira de Engenharia Agrícola e Ambiental, Campina Grande, v. 15, n. 4, p. 395-402, 2011.

PERPÉTUO, E. A. Parâmetros de caracterização da qualidade das águas e efluentes industriais. São Paulo: Cepema-USP, 2014. 90 p.

PESSÔA, Z. B. Efetivação do enquadramento de corpos-d'água para fins de consumo humano em regiões semiáridas: avaliação conforme Resolução Conama 357/2005 e Portaria MS 2.914/2011. Dissertação (Mestrado em Meio Ambiente, Águas e Saneamento) - Universidade Federal da Bahia, Escola Politécnica. Salvador, 2013. 124 p.

PINTO FILHO, J. L. de O.; SOUZA, R. F. de; PETTA, A. R. Avaliação da água para consumo humano nas comunidades rurais do Campo Petrolífero Canto do Amaro - CPCA, RN, Brasil. Sustentabilidade em Debate, v. 9, p. 102-119, 2018

Caracterização socioeconômica e ambiental da população do campo petrolífero Canto do Amaro, RN, Brasil. Sustentabilidade em Debate, v. 7, n. 2, p. 200-216, 2016. 
PONTES, A. G. V. et al. Os perímetros irrigados como estratégia geopolítica para o desenvolvimento do semiárido e suas implicações à saúde, ao trabalho e ao ambiente. Revista Ciência e Saúde Coletiva, v. 18, n. 11, 3213-3222 p, 2013.

PONTES, A. G. V. Saúde do Trabalhador e saúde ambiental: articulando universidade, SUS e movimentos sociais em território rural. 2012. 263 f. Dissertação (Mestrado em Saúde Coletiva). Universidade Federal do Ceará - UFC, Ceará, 2012.

QUESADO JÚNIOR, N. et al. Diagnóstico dos poços e qualidade das águas subterrâneas do município de Quixeré, Estado do Ceará. XV CONGRESSO BRASILEIRO DE ÁGUAS SUBTERRÂNEAS. Anais... Ceará, 2008.

RIBEIRO, T. G. et al. Estudo da Qualidade das Águas por Meio da Correlação de Parâmetros Físico-Químicos, Bacia Hidrográfica do Ribeirão Anicuns. Geochimica Brasiliensis, v. 30, p. 84-94, 2016.

RIGOTTO, R. M.; TEIXEIRA, A. C. A. Desenvolvimento e sustentabilidade socioambiental no campo, na cidade e na floresta. In: Caderno de Textos da I Conferência Nacional de Saúde Ambiental, 2009, Brasília. p. 78-83.

RIGOTTO, R. M. Agrotóxicos, trabalho e saúde: vulnerabilidade e resistência no contexto da modernização agrícola no Baixo Jaguaribe/CE. Fortaleza: UFC, 2011.

ROCHA, C. M. B. M. et al. Avaliação da qualidade da água e percepção higiênico-sanitária na área rural de Lavras, Minas Gerais, Brasil, 1999-2000. Cadernos de Saúde Pública, Rio de Janeiro, v. 22, n. 9, set. 2006.

RODRIGUES, L. M. et al. A Percepção Ambiental como Instrumento de Apoio na Gestão e na Formulação de Políticas Públicas Ambientais. Saúde e Sociedade, v. 21, supl. 3, p. 96-110, 2012.

SOARES, T. da C. et al. Perfil da água para o consumo humano e notificação de doenças em uma macrorregião do Piauí, Brasil. Revista Brasileira de Higiene e Sanidade Animal, v. 12, p. 205-215, 2018.

SOUSA, R. S. de. et al. Água e saúde no município de Igarapé-Açu, Pará. Saúde e Sociedade, São Paulo, v. 25, n. 4, p. 1095-1107, 2016.

TUCCI, C. E. M. Água no meio urbano. In: REBOUÇAS, A. da C. et al. (Org.). Águas doces no Brasil. 3. ed. São Paulo: Escrituras, 2006, p. 399-432.

TUNDISI, J. G. Água no século XXI enfrentando a escassez. São Carlos: RIMA/IIE. 2003, 247 p. São Carlos: Rima/IIE. 2005. 248 p.

TUNDISI, J. G.; TUNDISI, T. M. Limnologia. São Paulo: Oficina de Textos, 2009, 631 p.

VON SPERLING, M. Princípios do Tratamento Biológico de Águas residuárias. 3. ed. Departamento de Engenharia Sanitária e Ambiental/UFMG, Belo Horizonte, MG, 2005. 